\begin{tabular}{llll} 
MANAS Sosyal Araștırmalar Dergisi & 2019 & Cilt: 8 & Sayı: 4 \\
\hline MANAS Journal of Social Studies & 2019 & Vol.: 8 & No: 4
\end{tabular}

Atıfta Bulunmak İçin / Cite This Paper: Altıner, A. ve Erdem, Ş. (2019). "Uzun Dönem Denge Döviz Kuru ve Sapmalar: Beer Yaklaşımı”, Manas Sosyal Araştırmalar Dergisi, 8 (4): 3321-3351.

Araştırma Makalesi

\title{
UZUN DÖNEM DENGE DÖVIZ KURU VE SAPMALAR: BEER YAKLAŞIMI ${ }^{1}$
}

\author{
Ali ALTINER \\ Recep Tayyip Erdoğan Üniversitesi, İktisadi ve İdari Bilimler Fakültesi \\ alialtiner07@gmail.com \\ ORCID: 0000-0001-7362-8198
}

\author{
Şükrü ERDEM \\ Akdeniz Üniversitesi, İktisadi ve İdari Bilimler Fakültesi \\ meserdem@gmail.com \\ ORCID: 0000-0001-6416-6657
}

\begin{abstract}
Öz
Bu çalışmada, BEER (Davranışsal Denge Döviz Kuru) yaklaşımı ile cari açık sorunu yaşayan 15 gelişmekte olan ülke için 1995-2016 döneminde uzun dönem denge döviz kuru ve sapmaların belirlenmesi amaçlanmıştır. Uygulanan panel veri analizi neticesinde, uzun dönem denge reel efektif döviz kurunun en önemli belirleyicisinin göreli verimlilik olduğu tespit edilmiştir. Ayrıca net yabancı varlık stokundaki değişmelerin de önemli etkiler yarattığı gözlenmiştir. Elde edilen uzun dönem denge reel efektif döviz kuru değerleri, ulusal ve uluslararası ekonomik gelişmelere bağlı olarak denge düzeyinden sapmaların dönemden döneme ve ülkeye göre önemli farklılıklar gösterdiğini ortaya koymuştur. Buna göre, 2008 küresel krizinin reel efektif döviz kurları üzerinde önemli etkilerinin olduğu görülmüştür. Hindistan, Polonya, Hırvatistan ve Litvanya'da reel efektif döviz kurunun uzun dönem denge düzeyinden sapmasının diğer ülkelere oranla düşük oranda olduğu ancak Güney Afrika, Mısır, Gana, Kolombiya, Uruguay, Bulgaristan ve Tunus'ta yüksek oranda olduğu belirlenmiştir. Türkiye için elde edilen sonuçlar, reel efektif döviz kurunun seyrinin genel olarak krizlerin habercisi olduğunu göstermiştir. Reel efektif döviz kurunun 2003'ten itibaren küresel krizin etkilerinin hissedildiği 2009 yılına kadar hem yurtiçi hem de küresel ölçekteki gelişmelere bağlı olarak denge düzeyine göre aşırı değerli olduğu ve sonraki süreçte 2011 yllından itibaren yaşanan gelişmelere bağlı olarak düşük değerli bir görünüme sahip olduğu belirlenmiştir.
\end{abstract}

Anahtar Kelimeler: Davranışsal denge döviz kuru, Denge döviz kurundan sapma, Gelişmekte olan ülkeler, Panel veri analizi

\section{EQUILIBRIUM EXCHANGE RATES AND MISALIGNMENTS: THE BEER} APPROACH

\begin{abstract}
In this study, it was aimed to determine the long-run equilibrium exchange rates and misalignments for 15 developing countries with current account deficit in the period of 1995-2016 by using BEER (Behavioral Balance Exchange Rate) approach. As a result of the applied panel data analysis, it was determined that the most important determinant of long-term equilibrium real effective exchange rate is relative productivity. In addition, changes in the net foreign asset stock also have significant effects. The obtained long-run equilibrium real exchange rates showed that the misalignments from the equilibrium level differed significantly from period to period and according to country due to the national and international economic developments. Accordingly, the 2008 global crisis has had significant effects on real effective exchange rates. In India, Poland, Croatia and Lithuania, the
\end{abstract}

\footnotetext{
${ }^{1} \mathrm{Bu}$ çalışma, güncel veriler ve yeni ekonometrik teknikler kullanılarak "Denge Döviz Kuru: Gelişmekte Olan Ülkeler Üzerine Bir Uygulama" isimli doktora tezinden üretilmiştir.
} 
misalignments of the real effective exchange rate from the long-run equilibrium level was low compared to other countries, but it was found to be high in South Africa, Egypt, Ghana, Colombia, Uruguay, Bulgaria and Tunisia. The results obtained for Turkey show that the trend of real effective exchange rate is a precursor of crises. It was determined that the real effective exchange rate was overvalued than the equilibrium level due to the developments in both domestic and global scale from 2003 to 2009 when the effects of the global crisis were felt, but it has depreciated due to the developments in the following period beginning from 2011.

Key Words: Behavioral equilibrium exchange rates, Misalignment from equilibrium exchange rate, Developing countries, Panel data analysis

\section{GİRIŞ}

Döviz kuru, uluslararası mal, hizmet ve sermaye akımları üzerindeki etkisinin yanında ulusal gelir, yatırım, enflasyon, para arzı ve faiz gibi birçok makroekonomik değişkeni etkilemesi bakımından önemlidir. Ekonomik faaliyetleri etkileyen önemli unsurlardan biri olmasından dolayı, döviz kurlarının açıklanmasına yönelik farklı yaklaşımlar geliştirilmiştir. Bu kapsamda, döviz kurlarını açıklamaya yönelik geliştirilen ilk teoriler, sabit kur sistemlerine bağlı olarak dış ticaret üzerinde yoğunlaşmıştır. İkinci Dünya Savaşının sonundan 1970’lerin başına kadar, ülkelerde genellikle ayarlanabilir sabit döviz kuru rejimi olan Bretton Woods parasal sistemi uygulanmış olup, bu sistemin kullanıldığı yaklaşık 30 yıl boyunca kurlar çok fazla değişiklik göstermediğinden ve sermaye hareketleri sınırlı kaldığından, geleneksel yaklaşımlar geçerliliğini korumuştur.

1973 yllında Bretton Woods sisteminin çökmesiyle birlikte gelişmiş ülkelerin birçoğunda esnek döviz kuru sistemi uygulanmaya başlanmıştır. Ayrıca sermaye hareketlerindeki hızlanma ile birlikte döviz kurlarında sert dalgalanmalar veya oynaklık sorunu ortaya çıkmıştır. $\mathrm{Bu}$ gelişmeler, döviz kurunun belirlenmesine yönelik geliştirilen ilk teorilerin yetersiz kalmasına neden olmuştur. Gelişmekte olan ülkelerde ise 1980'li yllardan itibaren ticari ve finansal serbestleşme yaşanmıştır. $\mathrm{Bu}$ süreçte ülkeler arasında ekonomik entegrasyonun artması ve sermayenin dünya çapında sınırsız şekilde hareket etmesi, sermaye akımları arışıııı dış ticaret akımları artışından büyük olmasına yol açmıştır. Bu gelişmelerden dolayı sonraki dönemlerde, daha çok sermaye piyasalarına odaklanılmış ve döviz kurunun kısa dönem belirleyicileri dikkate alınmaya başlanmıştır. Ayrıca 1990'lı yıllarda sermaye hareketlerindeki artışla birlikte gelişmekte olan ülkelerde kur şoklarına bağlı finansal krizler meydana gelmiştir. Bu nedenle, günümüzde ekonomiler için döviz kurunun denge sağlayıcı seviyesinin belirlenmesi kritik önem taşımaktadır.

2000'li y1lların başından itibaren gelişmekte olan ülkelerin çoğunda olduğu gibi Türkiye'de de sermaye girişlerindeki artıştan dolayı reel efektif döviz kuru artı̧s eğilimine girmiş ve buna bağlı olarak ulusal para değerlenme süreci yaşamıştır. Aynı dönemde Türkiye'de sürekli ve büyük boyutta cari açıklar yaşanmıştır. Ekonomik dengeye ve 
dolayısıyla cari açığa etkisinin görülebilmesi amacıyla, reel efektif döviz kurlarının denge düzeylerinin araştırılıp, dengeden sapma boyutlarının belirlenmesi gerekliliği ortaya çıkmıştır. $\mathrm{Bu}$ incelemenin Türkiye gibi cari açık sorunu yaşayan diğer ülkeler için de yapılması, aynı sorunu yaşayan ülkelerde reel efektif döviz kurunun hem denge seviyelerinin ve sapmalarının belirlenmesi ve hem de etkilerinin karşılaştırılabilmesi açısından önemlidir.

$\mathrm{Bu}$ çalışmanın amacı, Türkiye gibi hem sermaye hareketlerinden ve döviz kuru belirsizliklerinden önemli düzeyde etkilenen hem de cari açık sorunu yaşayan 15 gelişmekte olan ülke için 1995-2016 döneminde denge döviz kuru tahmini yapmak ve denge kurdan sapmaları tespit etmektir. Bu kapsamda ikinci bölümde çalışmanın teorik temelini oluşturan Davranışsal Denge Döviz Kuru Yaklaşımı (BEER) açıklanmaktadır. Üçüncü bölümde, temel alınan denge döviz kuru modeline yönelik ilgili literatür özeti sunulmaktadır. Dördüncü bölümde ampirik analiz kısmında kullanılacak veri seti tanıtılarak, beşinci bölümde panel veri analizi gerçekleştirilmektedir. Çalışmanın son bölümünde ise genel bir değerlendirme ve politika önerileri yapılmaktadır. İlgili literatürde modern denge döviz kuru yöntemleriyle Türkiye için yapılmış çalışmaların sayısı oldukça kısıtlıdır. Bu çalışmanın beklenen katkısı Türkiye'nin de içinde olduğu cari açık sorunu yaşayan ülkelerde, döviz kurlarının denge değerinin hesaplanması ve özellikle denge kurdan sapmaların belirlenmesi yönünde olacaktır. Ayrıca bu çalışma, modern modellerle hesaplanan denge döviz kurunun tek fiyat yasasına dayalı uzun dönem denge döviz kurundan daha gerçekçi olup olmadığ öngörüsünde daha yararlı olup olmadığının belirlenebilmesi açısından da önemlidir.

\section{TEORIKK TEMEL}

BEER yaklaşımının temeli Macdonald (1997) ve Clark ve Macdonald (1998) tarafından yapılan çalışmalara dayanmaktadır. Bu yaklaşım, reel döviz kurunun dönemsel ya da geçici hareketlerinin kaynağını ve temel belirleyicilerinin değerlerini inceleyerek döviz kuru davranışını açıklamaya çalışır (Siregar, 2011: 16).

BEER yaklaşımı, güvencesiz faiz paritesi yaklaşımının basit varsayımlarından türetilmiş olup genellikle reel döviz kurunun dönemsel hareketlerinin analizi için kullanılmaktadır. Bu yaklaşımda ödemeler dengesindeki cari ve sermaye hesabı kalemlerinin, reel döviz kurunun önemli belirleyicileri olduğu varsayılmıştır (Macdonald, 2000: 20). Döviz kuru modeli için güvencesiz faiz paritesi koşulu;

$$
\begin{aligned}
& E_{t}\left(e_{t+1}\right)-e_{t}=-\left(i_{t}-i_{t}^{*}\right) \\
& E_{t}\left(e_{t+1}\right)=t \text { döneminde } t+1 \text { dönemi için beklenen nominal döviz kuru, } \\
& e_{t}=t \text { dönemindeki nominal döviz kuru olup yabancı para birimi başına ifade }
\end{aligned}
$$
edilebilen ulusal para birimidir. 
$i_{t}=$ yurtiçi nominal faiz oranı ve

$i_{t}^{*}=$ yurtdışı nominal faiz oranıdır.

$e_{t}$ değerindeki bir artış, yerli paranın değer kaybetmesi anlamına gelmektedir. Ayrıca Denklem (1)'in her iki tarafindan beklenen enflasyon farkı çıkarılırsa nominal faiz paritesi reel faiz paritesine dönüştürülerek, reel döviz kuru $\left(q_{t}\right), \mathrm{t}+1$ döneminde beklenen reel döviz kuru $\left(E_{t}\left(e_{t+1}\right)\right)$ 'nun ve reel faiz farkının $\left(r_{t}-r_{t}^{*}\right)$ bir fonksiyonu olarak elde edilir (IMF, 2007: 54);

$E_{t}\left(q_{t+1}\right)-q_{t}=-\left(r_{t}-r_{t}^{*}\right)$

$r_{t}=i_{t}-E_{t}\left(\Delta p_{t+1}\right)$

$r_{t}^{*}=i_{t}^{*}-E_{t}\left(\Delta p_{t+1}^{*}\right)$

Denklem (2), yeniden düzenlenirse,

$$
q_{t}=E_{t}\left(q_{t+1}\right)+\left(r_{t}-r_{t}^{*}\right)
$$

Denklem (3)'e göre reel döviz kuru $\left(q_{t}\right)$, reel döviz kurunun beklenen değeri ile yurtiçi ve yurtdışı reel faiz oranı farklarının bir fonksiyonu olur.

Teorik olarak BEER yaklaşımına göre, uzun dönem beklenen reel döviz kuru sadece ekonomik temellerin fonksiyonudur. Bu durumda, denge reel döviz kuru, aşağıdaki Denklem (4)’te gösterildiği gibi, uzun dönem ekonomik temeller ve kısa dönem yurtiçi ve yurtdışı reel faiz farkları bir araya getirilerek belirlenir,

$q_{t}^{B E E R}=f\left(Z_{t},\left(r_{t}-r_{t}^{*}\right)\right)$

Clark ve Macdonald (1998), BEER yaklaşımını daha açık gösterebilmek amacıyla ekonomik temeller vektörünün 3 uzun dönem belirleyici değişkeni olduğunu varsaymıştır. Buna göre uzun dönem denge reel döviz kuru aşağıdaki denklemde gösterilen 3 değişkenin fonksiyonudur;

$$
E_{t}\left(q_{t+1}\right)=f(\text { tot }, \text { tnt }, n f a)
$$

tot $=$ dış fiyat düzeyini gösteren diş ticaret haddi,

$t n t=$ Balassa-Samuelson etkisini gösteren ticareti yapılamayan mal fiyatlarının ticareti yapılabilen mal fiyatlarına göreli oranı,

$n f a=$ net dış pozisyonu gösteren net yabancı varlık stokudur.

Clark ve Macdonald (1998), BEER yaklaşımıyla ilgili bu açıklamaların yanında güvencesiz faiz paritesi koşuluna zamanla değişebilen risk primini ekleyerek cari denge reel döviz kurunun nasıl belirlendiğini incelemiştir. $\mathrm{Bu}$ durumda Denklem (4) yeniden düzenlenirse reel döviz kuru;

$q_{t}=E_{t}\left(q_{t+1}\right)+\left(r_{t}-r_{t}^{*}\right)-\pi$ 
olur. Zamanla değişebilen risk primi $(\pi)$ 'nin, yurtiçi kamu borcu/GSYH'nin yurtdışı kamu borcu/GSYH'ye oranı olduğu kabul edilmiştir. Bu durumda nihai olarak BEER yaklaşımına göre denge reel döviz kuru aşağıdaki şekilde elde edilebilmektedir:

$q_{t}^{B E E R}=f\left(\left(t o t, t n t, n f a,\left(r_{t}-r_{t}^{*}\right),\left(\frac{g d e b t}{g d e b t^{*}}\right)\right)\right.$

Clark ve Macdonald (1998) çalışmalarında, reel döviz kurunun cari denge değerini hesaplamak için reel efektif döviz kuru davranışını açıklayabilen indirgenmiş bir denklemin tahmin edilmesi gerekliliğini belirtmişlerdir. İndirgenmiş bir biçim eşitliği genel ifadelerle,

$q_{t}=\beta_{1} Z_{1 t}+\beta_{2} Z_{2 t}+\tau T_{t}+\varepsilon_{t}$

şeklinde gösterilebilir. Bu denklemde,

$Z_{1}=$ Uzun dönemde reel döviz kurunda kalıcı etkiler bırakması beklenen ekonomik temeller vektörü,

$Z_{2}=$ Orta dönemde reel döviz kurunu etkileyen ekonomik temeller vektörü,

$\beta_{1}, \beta_{2}, \tau=$ Katsayılar,

$T=$ Kısa dönemde reel döviz kurunu etkileyen geçici faktörler vektörü,

$\varepsilon=$ tesadüfi hata terimidir.

Denklem (8)'e göre cari reel efektif döviz kuru, temel ekonomik değişkenler ile birlikte kısa dönemde reel döviz kurunu etkileyen değişkenler ve hata terimi tarafından belirlenir. İki ekonomik temel setinin cari değerleriyle hesaplanan denge reel döviz kuru $\left(q^{\prime}\right)$ ndan cari reel döviz kurun ayrılması yararlı olur,

$q_{t}^{\prime}=\beta_{1} Z_{1 t}+\beta_{2} Z_{2 t}$

Denklem (9)'daki temel çerçeve kullanılarak, cari sapma, tüm ekonomik temellerin cari olarak göz önünde bulundurulmasıyla elde edilen denge reel döviz kuru ve cari reel döviz kuru arasındaki fark olarak belirlenebilir;

$c m_{t}=q_{t}-q_{t}^{\prime}=q_{t}-\beta_{1} Z_{1 t}-\beta_{2} Z_{2 t}=\tau T_{t}+\varepsilon_{t}$

Toplam sapma ise ekonomik temellerin sürdürülebilir ya da uzun dönem değerleri tarafından belirlenen denge reel döviz kuru ve cari reel döviz kuru arasındaki fark olarak tanımlanabilir,

$t m_{t}=q_{t}-\beta_{1} \bar{Z}_{1 t}-\beta_{2} \bar{Z}_{2 t}$

Denklem (11)'in sağ tarafından $q_{t}^{\prime}$ çıkarılarak, toplam sapma iki bileşene ayrıştırılabilir;

$t m_{t}=\left(q_{t}-q_{t}^{\prime}\right)+\left\lceil\beta_{1}\left(Z_{1 t}-\bar{Z}_{1 t}\right)+\beta_{2}\left(Z_{2 t}-\bar{Z}_{2 t}\right)\right\rceil$ 
Denklem (12)'deki birinci bileşen, Denklem (10)'da gösterilen basit bir cari sapmadır (Clark ve Macdonald,1998: 11).

Yukarıdaki açıklamalar ışığında, BEER yaklaşımına göre uzun dönem denge reel döviz kurunun belirleyicileri Denklem (5)'te açıklanmış olup, uzun denge reel döviz kurunun tahmini için ilk olarak ekonomik temellerin uzun dönem ya da sürdürülebilir değerlerinin belirlenmesi gereklidir. Uzun dönem değerler, HP (Hodrick-Prescott) filtresi ya da BeveridgeNelson ayrıştırma yöntemi kullanarak sürekli ya da geçici bileşenlerine ayırmayla ya da uzun dönem değerlerin subjektif bir değerlendirmesi yapılarak elde edilebilir. Sonraki aşamada toplam sapma olarak ifade edilen uzun dönem denge reel döviz kurundan sapmalar hesaplanır. $\mathrm{Bu}$ amaçla, ekonomik temellerin uzun dönem değerleri tahmin edilen ilişkiye dahil edilir ve kısa dönem değişkenler sıfıra eşitlenir. Toplam sapma, ekonomik temellerin sürdürülebilir değerleri kullanıldığında, reel döviz kurunun denge ve cari değerleri arasındaki fark olarak belirlenir (Egert vd.,2005: 20-21).

\section{LITERATÜR ÖZETI}

Bu bölümde ilk olarak BEER yaklaşımla ilgili ampirik çalışmalardan bazıları özet olarak Tablo 1'de sunulmuştur.

Tablo 1. BEER Yaklaşımına Yönelik Seçilmiş Bazı Ampirik Çalışmalar

\begin{tabular}{|c|c|c|c|c|}
\hline Çalışma & Dönem & Ülke & Açıklayıcı Değişkenler & Yöntem \\
\hline Feyzioğlu (1997) & $\begin{array}{l}\text { 1975:Q1- } \\
\text { 1995:Q1 }\end{array}$ & Finlandiya & $\begin{array}{l}\text { TOT, WIR, PROD, } 1991 \text { Sovyet } \\
\text { çöküşü için kukla değişken }\end{array}$ & J.E \\
\hline $\begin{array}{l}\text { Clark ve Macdonald } \\
\text { (1998) }\end{array}$ & $1960-1996$ & $\begin{array}{l}\text { ABD, Almanya } \\
\text { ve Japonya }\end{array}$ & $\begin{array}{l}\text { TOT, TNT, NFA, GOVD ve } \\
\text { RIRD }\end{array}$ & J.E \\
\hline $\begin{array}{l}\text { Clark and Macdonald } \\
(2000)\end{array}$ & $1960-1997$ & $\begin{array}{l}\text { ABD, İngiltere } \\
\text { ve Kanada }\end{array}$ & TNT, NFA ve RIRD & J.E \\
\hline Achy (2001) & $1970-1997$ & $\begin{array}{l}5 \text { Ortadoğu ve } \\
\text { Kuzey Afrika } \\
\text { Ülkesi (MENA) }\end{array}$ & $\begin{array}{l}\text { TOT, IMTAR, NTGOVE, NFA, } \\
\text { TEC }\end{array}$ & J.E \\
\hline Zhang (2001) & $1952-1997$ & Çin & RCS, GOVE, EX ve OPEN & J.E \\
\hline Akram (2003) & $\begin{array}{l}\text { 1972:Q1- } \\
\text { 2001:Q4 }\end{array}$ & Norveç & PROD, TOT, GOVE ve RIRD & J.E \\
\hline Alberola (2003) & $1960-2001$ & $\begin{array}{l}7 \text { Latin Amerika } \\
\text { Ülkesi }\end{array}$ & NFA ve PROD & J.E \\
\hline Schnatz vd. (2003) & $\begin{array}{l}\text { 1981:Q1- } \\
\text { 2001:Q1 }\end{array}$ & $\begin{array}{l}11 \mathrm{AB} \text { ülkesi ve } \\
\mathrm{ABD}\end{array}$ & $\begin{array}{l}\text { RIRD, OİL, GOVE, TE, WH, } \\
\text { RPR, RID }\end{array}$ & J.E \\
\hline Funke ve Rahn (2004) & $\begin{array}{l}\text { 1985:Q1- } \\
\text { 2002:Q4 }\end{array}$ & Çin & PROD ve NFA & J.E \\
\hline Macdonald (2004) & $\begin{array}{l}\text { 1983:Q1- } \\
\text { 2003:Q2 }\end{array}$ & Singapur & $\begin{array}{l}\text { NFA, PROD, TOT, OPEN, OG, } \\
\text { GOVE, PRIVE, AP }\end{array}$ & \\
\hline Wang (2004) & $1980-2003$ & Çin & NFA, PROD ve OPEN & J.E \\
\hline Chen(2005) & $\begin{array}{l}\text { 1994:Q1- } \\
\text { 2006:Q2 }\end{array}$ & Çin & TNT, NFA, TOT ve OPEN & J.E \\
\hline Cheng ve Orden (2005) & $1978-2002$ & Çin ve Hindistan & $\mathrm{BB}, \mathrm{CI}$ ve TOT & J.E \\
\hline $\begin{array}{l}\text { Dufrenot ve } \\
\text { Yehoue(2005) }\end{array}$ & $1979-2000$ & 64 GOÜ & $\begin{array}{l}\text { OPEN, GOVE, PROD, NFA, } \\
\text { Resmi gelişme Desteği, döviz } \\
\text { rezervi değişimi, Nominal } \\
\text { devalüasyon ve yurtiçi kredi artış } \\
\text { oranı }\end{array}$ & P.E. \\
\hline
\end{tabular}




\begin{tabular}{|c|c|c|c|c|}
\hline $\begin{array}{l}\text { Komarek ve Melecky } \\
(2005)\end{array}$ & $\begin{array}{l}\text { 1994:Q1- } \\
\text { 2004:Q1 }\end{array}$ & Çek Cumhuriyeti & $\begin{array}{l}\text { PROD, RIRD, TOT, FDI, NFA, } \\
\text { GOVE ve OPEN }\end{array}$ & ARDL \\
\hline Sahminan (2005) & $\begin{array}{l}\text { 1993:Q1- } \\
\text { 2005:Q2 }\end{array}$ & Endonezya & NFA, TOT, PROD ve RIRD & J.E \\
\hline Paiva (2006) & $\begin{array}{l}\text { 1970:Q1- } \\
\text { 2004:Q1 }\end{array}$ & Brezilya & $\begin{array}{l}\text { TNT, TOT, RIRD, NFA ve } \\
\text { GOVD }\end{array}$ & J.E \\
\hline Toulaboe (2006) & $1985-1999$ & 33 GOÜ & $\begin{array}{l}\text { GOVE, TOT, TB, RGDP ve } \\
\text { OPEN }\end{array}$ & J.E \\
\hline Villavicencio (2006) & $\begin{array}{l}\text { 1980:Q1- } \\
\text { 2005:Q4 }\end{array}$ & 8 GÜ ve 9 GOÜ & NFA ve PROD & P.E \\
\hline $\begin{array}{l}\text { Iossifov ve Loukoianova } \\
\text { (2007) }\end{array}$ & $\begin{array}{l}\text { 1984:Q1- } \\
\text { 2006:Q1 }\end{array}$ & Gana & $\begin{array}{l}\text { RIRD, TOT, OPEN, BB, NFA ve } \\
\text { PCGDP }\end{array}$ & J.E \\
\hline Leung ve Ng (2007) & $1987-2006$ & Hong Kong & $\begin{array}{l}\text { NFA, PROD, TOT, GOVE, } \\
\text { OPEN, MO }\end{array}$ & J.E \\
\hline Macdonald ve Dias(2007) & $\begin{array}{l}\text { 1988:Q1- } \\
\text { 2006:Q1 }\end{array}$ & 10 GÜ ve GOÜ & NFA, NEX, TOT, PCGDP & $\begin{array}{l}\text { P.E ve } \\
\text { J.E }\end{array}$ \\
\hline Yajie vd. (2007) & $1980-2004$ & Çin & M2, CBFEX ve PROD & J.E \\
\hline Jongwanich (2008) & $1970-2000$ & Tayland & $\begin{array}{l}\text { PROD, OPEN, PORIC, FDII, } \\
\text { GOVE, TOT }\end{array}$ & J.E \\
\hline Kinkyo (2008) & $\begin{array}{l}\text { 1981:Q1- } \\
\text { 2000:Q3 }\end{array}$ & Kore & $\begin{array}{l}\text { NFA, TOT, RIRD, PROD ve } \\
\text { GOVE }\end{array}$ & J.E \\
\hline Komaludin (2009) & $\begin{array}{l}\text { 2004:Q1- } \\
\text { 2008:Q1 }\end{array}$ & Endonezya & $\begin{array}{l}\text { REER (-1), RCS, RIRD, GOVE, } \\
\text { NFA, TOT, CA ve küresel kriz } \\
\text { için kukla değişken }\end{array}$ & J.E \\
\hline Alper (2010) & $\begin{array}{l}\text { 1989:Q1- } \\
\text { 2007:Q3 }\end{array}$ & Türkiye & NFA, PROD & J.E \\
\hline Benassy-Quere vd. (2010) & $1980-2005$ & 15 Ülke & NFA, TOT, PROD & J.E \\
\hline $\begin{array}{l}\text { MacDonald ve Vieira } \\
(2010)\end{array}$ & $1980-2004$ & 66 ülke & PCGDP, NFA, TOT ve GOVE & P.F.E \\
\hline Elbadawi vd. (2012) & $1980-2004$ & 83 Ülke & $\begin{array}{l}\text { NFA, PROD, TOT, OPEN, } \\
\text { GOVE, TAX ve AID }\end{array}$ & $\begin{array}{l}\text { PMG, } \\
\text { MG ve } \\
\text { DFE }\end{array}$ \\
\hline Rusek (2012) & $\begin{array}{l}\text { 1999:Q1- } \\
\text { 2011:Q3 }\end{array}$ & 7 AB ülkesi & $\begin{array}{l}\text { TOT, NFA, TNT, PROD, CA, } \\
\text { RIRD ve GOVD }\end{array}$ & J.E \\
\hline Plecita ve Strelec (2012) & $1999-2011$ & $\begin{array}{l}\text { Yunanistan ve } \\
\text { İlanda }\end{array}$ & RIRD, TNT, TOT, IIP ve RP & J.E \\
\hline Couharde vd. (2013) & $1985-2009$ & $\begin{array}{l}13 \text { WAEMU } \\
\text { ülkesi }\end{array}$ & $\begin{array}{l}\text { NFA, TOT, PROD, OPEN ve } \\
\text { GOVE }\end{array}$ & P.E, \\
\hline $\begin{array}{l}\text { Amoah ve Aziakpono } \\
(2015)\end{array}$ & $1980-2013$ & Gana & TOT, NFA, RIRD, LIM, LED & ARDL \\
\hline $\begin{array}{l}\text { Khomo ve Aziakpono } \\
\text { (2016) }\end{array}$ & $1985-2014$ & Güney Afrika & $\begin{array}{l}\text { PROD, TOT, OPEN, RIRD, CAP, } \\
\text { GOV }\end{array}$ & DOLS \\
\hline Tipoy vd. (2016) & $1980-2013$ & $\begin{array}{l}10 \text { Gelişmekte } \\
\text { Olan Ülke }\end{array}$ & NFA, PROD & PARDL \\
\hline Fidora vd. (2017) & $\begin{array}{l}\text { 1999: Q1- } \\
\text { 2016: Q3 }\end{array}$ & Euro Bölgesi & $\begin{array}{l}\text { PCGDP, OPEN, TOT, GOVE, } \\
\text { RIRD }\end{array}$ & PFE \\
\hline Adu vd. (2018) & $1980-2015$ & $\begin{array}{l}\text { Batı Afrika Para } \\
\text { Bölgesi } \\
\text { (WAMZ) }\end{array}$ & $\begin{array}{l}\text { PROD, GOV, OPEN, OIL, TOT, } \\
\text { RIR, }\end{array}$ & SVAR \\
\hline
\end{tabular}

Not: PFE: panel sabit etkiler modeli, PE: panel eşbütünleşme, JE: johansen eşbütünleşme testi, SVAR: Yapısal VAR, DOLS: Panel dinamik EKK, ARDL: ARDL sınır testi, ARDL: Panel ARDL sınır testi, NFA: net yabancı varlık stoku, TOT: dış ticaret haddi, PROD: Verimlilik, OPEN: ticari dışa açıklık, GOVD: kamu borç stoku, GOVE: kamu harcamaları, RIRD: reel faiz farkı, PCGDP: kişi başı GSYH, NEX: net ihracat, OG: çıktı açığı, PRIVC: özel tüketim harcamaları, AP: varlık fiyatları, PORIC: portföy yatııım girişi, FDII: DYY girişi, BB: bütçe dengesi, CI: Sermaye girişleri, MO: imalat sanayi üretim/GSYH, NFI: Net yabancı gelir, TAX: ticareti yapılamayan mallar için vergiler, AID: yardım girişleri, PMG: pooled mean Group, DFE: dinamik sabit etkiler, MG: More general Mean Group, M2D: para arzı fark1, RID: reel gelir fark1, OIL: reel petrol fiyatları, TE: toplam istihdam, WH: çalışma saatleri, RPR: göreli fiyat oranı, CA: cari denge, TNT: ticareti yapılamayan malların fiyatının ticareti yapılabilen malların fiyatına oranı, IIP: uluslar arası yatırım pozisyonu, RP: risk primi, WIR: dünya faiz oranı, CBFEX: merkez bankası döviz rezervleri, REER(-1): bir dönem gecikmeli reel efektif döviz kuru, RCS: reel sermaye stoku, İMTAR: ithalat tarifeleri, NTGOVE: ticareti yapılamayan mallar için kamu harcamaları, TEC: teknolojik ilerleme, EX: ihracat artış oranı, TB: ticaret dengesi, LIM: İthalat/GDP oran, LED: Dış borç stoku, CAP: Sermaye giriş ve çıkış miktarı. 
Tablo 1'e göre, BEER model kapsamında değerlendirilebilecek çalışmalarda pek çok farklı ülke ve dönem için döviz kurunun belirleyicilerinin incelendiği görülmektedir. Yapılan çalışmalarda genellikle kısa ve uzun dönem ekonomik temellerin bir arada kullanıldığı ve dolayısıyla cari denge döviz kurun belirlenmesi için ampirik analizler yapıldığı belirlenmiştir. Ayrıca ampirik analiz yöntemi olarak genel olarak zaman serisi tekniklerinin kullanıldığı tespit edilmiştir. $\mathrm{Bu}$ nedenle, çalışmamızda literatürde olası bir boşluğu dolduracağından hareketle denge döviz kurunun belirlenmesi amacıyla panel veri teknikleri kullanılmıștır.

\section{VERİ SETİ}

Çalışmada cari açık sorunu yaşayan ve GSYH'si diğerlerine göre nispeten yüksek olan yüksek-orta gelir grubundaki 15 Gelişmekte Olan Ülke² için 1995-2016 dönemi yıllık verileri kullanılarak denge döviz kuru tahminleri yapmak ve sapmaları belirlemektir. Veri seti Clark ve Macdonald (1998) modeli kapsamında teorik kısımda açıklanmış olan Denklem (5) temel alınarak oluşturulmuştur. Bağımlı değişken olan döviz kurunu temsilen reel efektif döviz kuru endeksi; bağımsız değişkenler için ise net dış pozisyonu temsilen net yabancı varlık stoku, Balassa-Samuelson etkisini temsilen göreli verimlilik ve diş fiyatları temsil etmek üzere dış ticaret haddi verileri kullanılmıştır. Değişkenlerin elde ediliş süreci ve analiz kapsamında teorik açıdan beklenen işaretleri aşağıda detaylı olarak açıklanmıştır;

Reel Efektif Döviz Kuru (REER): Çalışmada kullanılan reel efektif döviz kuru endeksi serileri bruegel.org web adresinden alınmıştır. Çalışmada kullanılan REER, Darvas (2012) tarafindan şu şekilde hesaplanmıştır;

$R E E R_{t}=\frac{N E E R_{t} \times C P I_{t}}{C P I_{t}^{(\text {foreign })}}$,

Bu denklemde:

$R E E R_{t}$, ticari partnerlerin para birimleri sepetine karşı ülkenin reel efektif döviz kuru endeksini,

$N E E R_{t}=\prod_{i=1}^{N} S(i)_{t}^{w^{(i)}}$, ülkenin nominal efektif döviz kuru olup, ulusal para birimi başına yabancı para birimi olarak ifade edilen nominal döviz kurunun $(S(i))$ geometrik olarak ağırlıklı ortalamasını,

$C P I_{t}=$ Yurtiçi tüketici fiyat endeksini,

$C P I_{t}^{(f o r e i g n)}=\prod_{i=1}^{N} C P I(i)_{t}^{w^{(i)}}$, ticari partnerlerin tüketici fiyat endekslerinin geometrik olarak ağırlıklı ortalaması olup, $C P I(i)$ ve $w^{(i)}$ sırasıyla ticari partner $i$ ülkesinin tüketici fiyat endeksini ve ağırlığını gösterirken, $N$ ise incelenen ticari partner sayısını temsil

\footnotetext{
215 Gelişmekte Olan Ülke: Türkiye, Hindistan, Meksika, Polonya, Güney Afrika, Romanya, Hırvatistan, Uruguay, Bulgaristan, Tunus, Kolombiya, Macaristan, Litvanya, Belarus ve Gana.
} 
etmektedir. REER endeksindeki bir artış, ulusal para biriminin sepete dahil edilen ticari partnerlerin para birimlerine karşı değerlendiğini göstermektedir (Darvas, 2012: 2).

Net Yabancı Varlık Stoku (NFA): Çalışmada kullanılan net yabancı varlık stoku değişkeni (NFA), Lane ve Milesi-Ferretti (2001) tarafından hesaplanan net yabancı varlık stokunun GSYH'ye oranı olup, ilgili web adresinden temin edilmiştir. Lane ve Milesi-Ferretti (2001), net yabancı varlık stokunu şu şekilde hesaplamışlardır;

Bir ülkenin net dış pozisyonu olan NFA, net borç pozisyonu, net finansal varlık pozisyonu ve net doğrudan yabancı yatırım pozisyonunun toplamıyla belirlenir,

$$
N F A_{t}=F D I A_{t}^{*}+E Q A_{t}^{*}+D E B T A_{t}^{*}+F X-F D I L_{t}^{*}-E Q L_{t}^{*}-D E B T L_{t}^{*}
$$

Eşitlikte $F D I A(L)_{t}^{*}, E Q A(L)_{t}^{*}, D E B T A(L)_{t}^{*}$, FX sırasıyla doğrudan yabancı yatırım varlıkları(yükümlülükleri), finansal varlıklar(yükümlülükler), borçlanma varlıkları (yükümlülükleri) ve döviz rezervlerini göstermektedir.

Veriler en son 2014 yılına kadar oluşturulduğundan, 2015 ve 2016 y1lı değerleri Villavicencio (2006) ve diğer bazı çalışmalarda olduğu gibi, 2014 ve 2015 yılı $n f a$ miktarlarına 2015 ve 2016 yılı cari hesap dengesi miktarı eklenerek hesaplanmıştır. Teorik olarak, net yabancı varlık stokundaki artışın REER'yi pozitif etkilemesi beklenmektedir. Şöyle ki; örneğin ödemeler dengesinde meydana gelen bir cari açık dış borçlarla finanse edilebileceği için net diş borçlulukta artışa yol açar (NFA düşer). Bu durumda borçluluğu artan ülke, borçlarını ödeyebilmek için uluslararası fiyatlar açısından rekabet üstünlüğüne sahip olmalıdır. Bu bakımdan borçlu ülke ulusal para biriminin değerini diğer para birimlerine karşı düşürerek (REER düşer) ihracatını arttırmaya çalışır. Kısacası döviz rezervlerini arttırarak borç yükümlülüklerini azaltmaya çalışır. Buna göre NFA'daki düşüş (artış) REER'de düşüşe (artışa) yol açmaktadır.

Göreli Verimlilik (PROD): Döviz kuru üzerinde Balassa-Samuleson etkisini göstermek noktasında biri dolaylı (INT) diğeri doğrudan (PROD) olmak üzere iki alternatif yaklaşım vardır. Dolaylı yaklaşıma göre, genellikle yurtiçi ve yurtdışı (en önemli ticaret partneri ülkelerin) tüketici fiyatlarının $\left(P_{t}^{C P I}\right.$ ve $\left.P_{t}^{F, C P I}\right)$ üretici fiyatlarına $\left(P_{t}^{W P I}\right.$ ve $\left.P_{t}^{F, W P I}\right)$ oranlanmasıyla göreli fiyatlar hesaplanır ve ticareti yapılabilen mallar sektöründeki verimlilik artışlarının etkisi belirlenmeye çalışılır:

$I N T=\left(\frac{P_{t}^{C P I}}{P_{t}^{W P I}} / \frac{P_{t}^{F, C P I}}{P_{t}^{F, W P I}}\right)$

Dolaysız yaklaşıma göre ise göreli verimlilik, yurtiçi ve yurtdışı toplam işgücü verimlilikleri farkı olarak ölçülür. Verimlilik, GSYH (Y)'nin çalışan sayısına (EM) bölünmesiyle elde edilir. Buna göre göreli verimlilik: 
$P R O D=\left(\frac{Y_{t}}{E M_{t}} / \frac{Y_{t}^{F}}{E M_{t}^{F}}\right)$

şeklinde elde edilir (Maeso-Fernandez vd. 2002: 441). Bu çalışmada Balassa-Samuelson etkisini göstermek amacıyla dolaysız yaklaşım (PROD) kullanılmıştır. Verimlilikteki artış, ticareti yapılabilen malların olduğu sektördeki ücretleri artırır. Bu durumda ücretlerin daha az olduğu ticareti yapılamayan mallar sektöründen ticareti yapılabilen mallar sektörüne emek akımı gerçekleşecektir. Ticareti yapılamayan mallar sektöründen ticareti yapılabilen mallar sektörüne emek akımı olması, ticareti yapılamayan mallar sektöründe ekonomik faaliyetlerin zayıflayarak karlılığın düşmesi demektir. Bunun engellemesi için ticareti yapılamayan mallar sektöründe verimlilik artışı olmamasına rağmen emek ücretlerinde artış meydana gelir. Yani ekonomide genel olarak çalışan başına GSYH yükselmiş olur. Bunun sonucunda maliyetlerde artış gerçekleşeceğinden, maliyet artışları fiyatlara yansıtılarak telafi edilir. Sonuçta genel olarak ekonomide fiyat düzeyi artarak CPI artar. $\mathrm{Bu}$ durum, dolaylı yaklaşım ve dolaysız yaklaşımda pay kısmının yani bölünen değerin artmasıyla ifade edilebilir. CPI'nın artması ise Denklem (13)’teki formüle göre REER'nin artmasına neden olur. İlgili değişkene ait veriler, Uluslararası Çalışma Örgütü (ILO) ve Dünya Bankası veri tabanından elde edilmiştir.

Dış Ticaret Haddi (TOT): İhracat fiyatlarının ithalat fiyatlarına oranı olarak tanımlanır $\left(\frac{\text { ihracat fiyat endeksi }}{\text { ithalat fiyat endeksi }}\right)$. Dış ticaret haddi, bir ülkenin karşı karşıya olduğu dış fiyatları yansıtır. Dış ticaret haddinin REER üstündeki etkisi, gelir etkisi ve ikame etkisinden hangisinin daha üstün olduğuna bağlıdır. Dış ticaret haddinin gelir etkisi şöyle açıklanabilir; ihracat fiyatlarındaki artış sonucu ihracat gelirleri artarak ülkeye döviz girişi artar. İthalat talebi ve dolayısıyla döviz talebi sabit iken, ülkedeki döviz miktarının artmasıyla döviz arz fazlası meydana gelerek ulusal para değerlenir ve REER artar. Yani dış ticaret haddindeki artışın gelir etkisi REER'yi arttırıcı niteliktedir. Dış Ticaret haddinin ikame etkisine göre ise, ihraç edilen mal talep esnekliği yüksek ise ihracat fiyatlarındaki artış sonucu ihracat miktarı düşer ve ülkeye döviz girişi azalır. İthalat talebi ve dolayısıyla döviz talebi sabit iken, ülkedeki döviz miktarının düşmesiyle döviz talep fazlası meydana gelerek ulusal para değersizleşir ve REER düşer. Yani dış ticaret haddindeki artışın ikame etkisi REER'yi düşürücü niteliktedir. Dolayısıyla bir ülkede dış ticaret haddindeki artış sonucu gelir etkisi ikame etkisinden daha yüksek olursa, döviz arz fazlası oluşarak REER artar. Eğer ikame etkisi gelir etkisinden yüksek olursa, döviz talep fazlası oluşarak REER düşer. Kısacası dış ticaret haddinin döviz kuru üstündeki etkisi, gelir ve ikame etkisinden hangisinin yüksek 
olacağına bağlı olarak belirsizdir. İlgili değişkene ait veriler, Dünya Bankası veri tabanından temin edilmiştir.

Değişkenlerin uzun dönem değerleri, literatür incelemesi doğrultusunda bir çok çalışmada olduğu gibi HP filtresi kullanılarak elde edilmiştir.

\section{EKONOMETRIK YÖNTEM}

Ampirik analiz kısmı 5 aşamadan oluşmaktadır. İlk olarak seriler arasında yatay kesit bağımlılığının varlığı $C D L M_{1}, C D L M_{2}$ ve $C D L M_{a d j}$ testleriyle sınanmıştır. Daha sonra SURADF (Seemingly Unrelated Regression Augmented Dickey Fuller) ikinci nesil birim kök testi ile serilerin durağanlığı incelenmiştir. Üçüncü aşamada, değişken katsayılarının homojen ya da heterojen olduğunun belirlenmesi amacıyla Delta Testi kullanılmıştır. Dördüncü aşamada, Durbin-Hausman eşbütünleşme testi ile seriler arasında uzun dönemde ilişki olup olmadığı belirlenmiştir. Son olarak beşinci aşamada ise değişkenlere ait katsayı tahminleri yapmak üzere DSUR (Dynamcis SUR) yöntemi ve sabit etkiler modeli kullanılmıştır.

\subsection{Yatay Kesit Bağımlılığı Testi}

Breusch ve Pagan (1980) tarafından yatay kesit bağımlılığının test edilmesi için oluşturulan LM istatistiği,

$C D L M_{1}=T \sum_{i=1}^{N-1} \sum_{j=i+1}^{N} \hat{\rho}_{i j}^{2}$

$\hat{\rho}_{i j}$, kalıntıların ikili korelasyonun tahmini olup,

$\hat{\rho}_{i j}=\hat{\rho}_{j i}=\frac{\sum_{t=1}^{T} e_{i t} e_{j t}}{\left(\sum_{t=1}^{T} e_{i t}^{2}\right)^{1 / 2}\left(\sum_{t=1}^{T} e_{j t}^{2}\right)^{1 / 2}}$

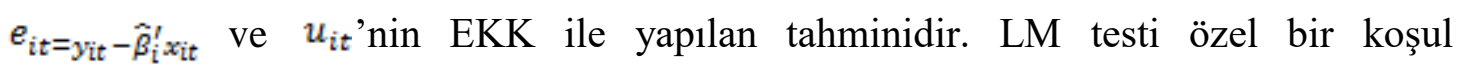
gerektirmez ve T> N durumlarında kullanılabilir. Ancak bu test geliştirilmiş olup, $C D L M_{2}$ testi elde edilmiştir:

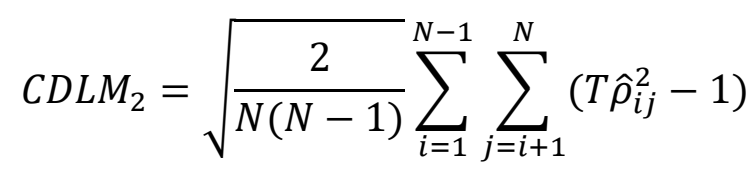

Bu teste göre $T \rightarrow \infty$ ve $N \rightarrow \infty$ olduğunda, sıfır hipotezine göre yatay kesit bağımlılığının olmadığı kabul edilir (Pesaran, 2004: 6-7). Ayrıca Pesaran vd. (2008) tarafından LM istatistiğine yapılan bir düzeltmeyle $\mathrm{N}>\mathrm{T}$ olduğunda da kullanılabilen bir test geliştirilmiştir;

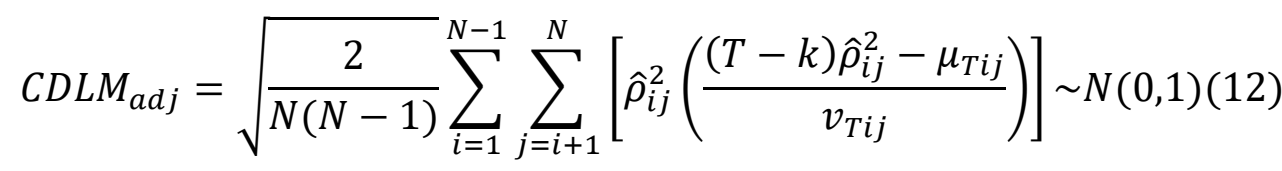


Denklemde $\mu_{T i j}$ ortalamayı, $v_{T i j}$ varyansı göstermektedir. Düzeltilmiş CDLM testi olarak isimlendirilen bu test, $\mathrm{N}>\mathrm{T}$ ve $\mathrm{T}>\mathrm{N}$ iken yatay kesit bağımlılığını sapmasız olarak tahmin edebilmektedir (Pesaran vd. 2008: 1-4).

\subsection{SURADF Birim Kök Testi}

Breuer vd. (2001) tarafından geliştirilen bu test, SUR (Seemingly Unrelated Regression- Görünürde İlişkisiz Regresyon) panel tahmin yöntemine bağlı bir ADF testidir. SURADF testi aşağıdaki Denklem (21) ile gösterilmektedir;

$$
\begin{aligned}
& \Delta y_{1, t}=\alpha_{1}+\left(\rho_{1}-1\right) y_{1, t-1}+\sum_{i=1} \delta_{i} \Delta y_{1, t-i}+u_{1, t} \\
& \Delta y_{2, t}=\alpha_{2}+\left(\rho_{2}-1\right) y_{2, t-1}+\sum_{i=1} \delta_{i} \Delta y_{2, t-i}+u_{2, t}
\end{aligned}
$$

$\Delta y_{N, t}=\alpha_{N}+\left(\rho_{N}-1\right) y_{N, t-1}+\sum_{i=1} \delta_{i} \Delta y_{N, t-i}+u_{N, t}$

Denklemde $\rho_{i}$, i serisi için otoregresyon katsayısıdır. Bu sistem SUR yöntemiyle tahmin edilir ve her $\left(\rho_{i}-1\right)$ 'in anlamlılığı simulasyonla elde edilen kritik değerlere karşı test edilir. Bu modelin spesifikasyonu, Levin ve Lin tarafından geliştirilen panel birim kök testine göre bir çok üstünlüğe sahiptir. İlk olarak SUR tahimini hata terimleri arasındaki yatay kesit bağımlılığını hesaba kattığından, tek denklemli ADF ve Levin ve Lin $(1992,1993)$ testlerine göre daha fazla bilgi verir. İkinci olarak, denklem paneli oluşturulan birimler arasında gecikme uzunluğunun farklı olduğunu varsayar. Birimlere özgü gecikme uzunluklarının olduğunu varsaymak denklemlerde yanlış belirleme sorununu ortadan kaldırır ve hata terimlerinin her birinin beyaz gürültülü olmasını sağlar. Paneli oluşturan birimler arasında ortak bir gecikme uzunluğu belirlemek test istatistiklerinin sapmalı olmasına yol açar. Ancak SURADF yönteminde, bir gecikme her bir birim için otokorelasyonun varlığını ortadan kaldırmak için yeterlidir. Üçüncüsü, spesifikasyon birimler arasında otoregresif katsayıların farklı olmasına izin verir. Yöntemde $\left(\rho_{1}-1\right)=\left(\rho_{2}-1\right)=\cdots=\left(\rho_{N}-1\right)$ sinırlaması kaldırılmış olup, böylece tüm serilerin birim köke sahip olduğu şeklindeki boş hipotezi ile tüm serilerin aynı otoregresif katsayı ile durağan olduğunu ifade eden alternatif hipotezden kaçınılmıştır. Yani bu testte, SUR çerçevesinde paneli oluşturan her bir birim için boş ve alternatif hipotezlerin hesaplanabilmesi mümkündür.

$\mathrm{N}$ sayıda birim için oluşturulan boş ve alternatif hipotezler aşağıdaki gibidir: 
$H_{0}^{1}: \beta_{1}=0 ; H_{A}^{1}: \beta_{1}<0$

$H_{0}^{2}: \beta_{2}=0 ; H_{A}^{2}: \beta_{2}<0$

$H_{0}^{N}: \beta_{N}=0 ; H_{A}^{N}: \beta_{2}<0$

SURADF test istatistiğinin kritik değerden küçük olması serinin durağan olduğunu ifade etmektedir (Breuer vd. 2001: 487; Breuer vd. 2002: 531).

\subsection{Homojenlik Testi}

Eğim katsayılarının homojen ya da heterojen olduğunun belirlenmesi uygulanacak eşbütünleşme testi için önemlidir. Pesaran ve Yamagata (2008) tarafından geliştirilen Delta $(\widehat{\Delta})$ testleriyle eğim katsayılarının homojenliği araştırılmaktadır. Büyük örneklemler için $\widehat{\Delta}$ testi, küçük örneklemler için ise $\widehat{\Delta}_{a d j}$ testi kullanılabilmektedir:

$\widehat{\Delta}=\sqrt{N}\left(\frac{N^{-1} \hat{S}-k}{\sqrt{2 k}}\right)$

$\widehat{\Delta}_{a d j}=\sqrt{N}\left(\frac{N^{-1} \hat{S}-E\left(\hat{z}_{i T}\right)}{\sqrt{\operatorname{Var}\left(\hat{z}_{i T)}\right.}}\right)$

$Y_{i t}=\propto_{i}+\beta_{i} X_{i t}+\varepsilon_{i t}, \quad i=1 \ldots \ldots . . ., \quad t=1 \ldots \ldots T$

(24) nolu denklemin tahmini için kullanılan, testlerin sıfır ve alternatif hipotezleri aşağıdaki gibidir;

$H_{0}: \beta_{i}=\beta$ yani eğim katsayıları homojendir.

$H_{a}: \beta_{i} \neq \beta$ yani eğim katsayıları homojen değildir (Pesaran ve Yamagata, 2008: 55-64).

\subsection{Eşbütünleşme Testi}

Çalışmada serilerin bazıları durağan ve bazıları durağan olmadığından, modelde eşbütünleşme katsayıları heterojen olduğundan ve yatay kesit birimleri arasında bağımlılık bulunduğundan buna uygun şekilde Westerlund (2008) tarafından geliştirilen Durbin-Hausman eşbütünleşme testi kullanılmıştır. Test, değişkenlerden bazılarının durağan olduğu ve bazılarının durağan olmadığı durumda kullanılabilmektedir. Test iki şekilde hesaplanabilmektedir. Bunlardan biri parametrenin heterojen olduğunu kabul eden grup ortalaması istatistiği $\left(D H_{g}\right)$ ve ikincisi ise parametrenin homojen olduğunu varsayan panel istatistiği $\left(\mathrm{DH}_{p}\right)^{\prime}$ 'dir;

$$
\begin{aligned}
& D H_{g}=\sum_{i=1}^{n} \hat{S}_{i}\left(\widehat{\emptyset}_{i}-\widehat{\emptyset}_{i}\right)^{2} \sum_{t=2}^{T} \hat{e}_{i t-1}^{2} \\
& D H_{p}=\hat{S}_{n}(\widehat{\varnothing}-\widehat{\emptyset})^{2} \sum_{i=1}^{n} \sum_{t=2}^{T} \hat{e}_{i t-1}^{2}
\end{aligned}
$$


$D H_{p}$ ve $D H_{g}$ için $H_{0}$ hipotezi her iki test için de "tüm birimler için eşbütünleşme yoktur." şeklinde oluşturulmuştur. Alternatif hipotezler $H_{1}^{p}$, “tüm panel için eşbütünleşme vardır." ve $H_{1}^{g}$ ise "bazı birimler için eşbütünleşme vardır." şeklinde oluşturulmuştur (Westerlund, 2008: 199-203).

\subsection{Uzun Dönem Eşbütünleşme Katsayılarının Tahmini}

\subsubsection{DSUR Tahmincisi}

DSUR yöntemi, Park ve Ogaki (1991) tarafından önerilen görünürde ilişkisiz eşbütünleşme regresyonlarının (SUR) parametrik olmayan tahmincilerinin parametrik bir alternatifidir. Ayrıca asimptotik olarak bu parametrik olmayan tahmincilere eşdeğerdir. DSUR yöntemi yatay kesit boyutunun zaman boyutundan küçük olduğu $(\mathrm{N}<\mathrm{T})$ ve eşbütünleşme vektörlerinin denklemler arasında homojen ya da heterojen olduğu dengeli paneller için uygundur. $\mathrm{Bu}$ yöntem, regresyondaki açıklayıcı değişkenler heterojen olduğunda ve hata terimleri arasında korelasyon olduğunda DOLS (Dynamic ordinary least squares) gibi sistematik olmayan metotlara karşı önemli bir etkinlik gücüne sahiptir (Mark vd., 2005: 797-798).

\subsubsection{Sabit Etkiler Modeli ile Katsayı Tahmini}

Panel veri analizinin kapsamını oluşturan temel model aşağıdaki gibidir;

$$
y_{\text {it }}=x_{i t}^{\prime} \beta_{i t}+\varepsilon_{i t}
$$

$\beta_{i t} \mathrm{i}$ birimi için $\mathrm{t}$ döneminde $\mathrm{x}_{\mathrm{it}}$ 'nin etkisini ölçer. $\mathrm{Bu}$ model geneldir ve $\beta_{\mathrm{it}}$ katsayısı tahmininde bazı varsayımların yapılmasını gerektirir. Nihai olarak model aşağıdaki gibi yazılabilir;

$$
y_{i t}=\mu+x_{i t}^{\prime} \beta+\propto_{i}+\varepsilon_{i t}
$$

$\mu$, her birime ait bireysel farklılıkları dikkate alan gözlenemeyen hata bileşenini göstermektedir. Çoğu panel veri analizinde sabit etkiler modeli ya da tesadüfi etkiler modeli kullanılır (Verbeek, 2004: 342-343; Gujarati ve Porter, 2007: 602-603). Sabit etkiler modelinde, eğim katsayısının tüm birimler için aynı olduğu kabul edilirken, sabit terimin zamana göre değişmediği ancak birime göre değiştiği (birim etki) ya da zamana göre değişirken birimler arasında değişmediği varsayılmaktadır. Bu bakımdan, sabit terimdeki farklılıkların birim etki ya da zaman etkisi ile ortaya çıktığı model tek yönlü sabit etkiler modeli olarak adlandırılırken, farklılıkların hem birim hem de zaman etkisinden kaynaklandığı modele ise iki yönlü sabit etkiler modeli denir. Tesadüfi etkiler modeli, bireysel etkileri gösteren sabit terimin değişken olduğunu varsayar. Bu yüzden, bu yaklaşımda yatay kesit birimleri arasındaki farklılığın tesadüfi olarak ortaya çıktığı kabul edilir. Benzer şekilde, birim ve/veya zaman etkilerinin olduğu varsayımıyla, model tek ya da iki yönlü tesadüfi etkiler yaklaşımıyla tahmin edilebilir (Hill vd., 2011: 543; Çemrek ve Burhan, 2014: 
50; Çetin ve Ecevit, 2010: 172). İlk olarak testlerle birim ve/veya zaman etkileri saptand1ktan sonra, bu etkilerin sabit mi yoksa tesadüfi mi olduğu belirlenmelidir. Bu belirleme Hausman (1978) spesifikasyon testi ile yapılmaktadır. Hausman testinde temel hipotez $\left(H_{0}\right)$, "açıklayıcı değişkenler ve birim etki arasında korelasyon yoktur” şeklinde iken, alternatif hipotez $\left(H_{a}\right)$ ise "açıklayıcı değişkenler ile birim etki arasında korelasyon vardır" şeklindedir. Hesaplanan olasılık değeri 0.05 'ten küçük çıkarsa $H_{a}$ hipotezi kabul edilir ve tahminler sabit etkiler modeliyle gerçekleştirilir. Ancak hesaplanan olasılık değerinin 0.05 'ten büyük olduğu tespit edilirse $H_{0}$ hipotezi kabul edilir ve tahminler tesadüfi etkiler modeliyle gerçekleştirilir (Tatoğlu, 2012: 179-182).

\section{AMPIRIIK BULGULAR}

\subsection{Panel Zaman Serisi Analiz Sonuçları}

Cari açık sorunu yaşayan üst orta gelir grubundaki 15 ülkede denge döviz kurunun belirlenmesi amacıyla yapılan panel veri analizi kapsamında, başlangıç olarak değişkenler ve modelde birimler arasında yatay kesit bağımlılığının olup olmadığı araştırılmıştır. Elde edilen analiz bulguları aşağıdaki Tablo 2'de verilmiştir.

Tablo 2. Yatay Kesit Bağımlılığı Testi Sonuçları

\begin{tabular}{|c|c|c|c|c|c|c|}
\hline Değişkenler & $C D L M_{1}$ & $\begin{array}{l}\text { Olasılık } \\
\text { Değeri }\end{array}$ & $C D L M_{2}$ & $\begin{array}{l}\text { Olasilık } \\
\text { Değeri }\end{array}$ & $C D L M_{a d j}$ & $\begin{array}{l}\text { Olasılık } \\
\text { Değeri }\end{array}$ \\
\hline REER & $335.018 * * *$ & 0.000 & $15.873 * * *$ & 0.000 & $12.162 * * *$ & 0.000 \\
\hline NFA & 328.126 *** & 0.000 & $15.397 * * *$ & 0.000 & $26.268 * * *$ & 0.000 \\
\hline PROD & $249.979 * * *$ & 0.000 & $10.005 * * *$ & 0.000 & $42.336 * * *$ & 0.000 \\
\hline TOT & $428.664 * * *$ & 0.000 & $22.335 * * *$ & 0.000 & $8.127 * * *$ & 0.000 \\
\hline Model & $357.930 * * *$ & 0.000 & $17.454 * * *$ & 0.000 & $13.726 * * *$ & 0.000 \\
\hline
\end{tabular}

Tablo 2'de gösterilen $C D L M_{1}, C D L M_{2}$ ve $C D L M_{a d j}$ testi sonuçlarına göre, tüm serilerde ve modelde \% 1 anlamlılık düzeyinde yatay kesit bağımlılığının söz konusu olduğu bulunmuştur. Değişkenlerin yatay kesit bağımlılığına sahip olduğu belirlendiğinden uygulanacak birim kök testi yatay kesit bağımlılı̆̆ını dikkate alan 2. nesil birim kök testi olmaktadır.

Değişkenlerin durağanlıklarının test edilmesi amacıyla gerçekleştirilen SURADF panel birim kök testi sonuçları aşağıdaki Tablo 3, Tablo 4, Tablo 5 ve Tablo 6'te sunulmuştur. 
Tablo 3. REER Değiş̧keni İçin Durağanlık Testi Sonuçları

\begin{tabular}{lrrrr}
\hline & & \multicolumn{3}{c}{ Kritik Dĕgerler } \\
\cline { 3 - 5 } Ülke & SURADF test & $1 \%$ & $5 \%$ & $10 \%$ \\
\hline Türkiye & -6.079 & -18.189 & -12.695 & -10.917 \\
Belarus & 3.497 & -159.803 & -135.965 & -124.547 \\
Hindistan & 7.534 & -18.602 & -12.183 & -9.837 \\
Meksika & -0.481 & -23.672 & -17.221 & -15.161 \\
Polonya & -3.437 & -15.872 & -10.943 & -8.893 \\
Güney Afrika & -3.735 & -21.346 & -15.384 & -12.856 \\
Misir & -6.193 & 14.788 & 18.694 & 21.543 \\
Romanya & -6.585 & -19.543 & -13.654 & -11.633 \\
Gana & 4.102 & -93.259 & -80.917 & -76.300 \\
Kolombiya & -10.013 & -18.807 & -13.004 & -10.994 \\
Hirvatistan & -10.293 & -23.152 & -15.361 & -12.793 \\
Uruguay & -1.994 & 16.168 & 20.342 & 23.407 \\
Bulgaristan & -4.929 & -145.577 & -126.118 & -117.059 \\
Tunus & -6.462 & -35.576 & -19.552 & -15.493 \\
Litvanya & -5.320 & -62.522 & -20.159 & -12.724 \\
\hline Not:
\end{tabular}

Not: $* * *, * * *$ sırasıyla istatistiki olarak \%1, \%5 ve \%10 anlamlılık düzeyinde durağanlığı göstermektedir. Kritik değerler, 10.000 döngüyle Monte Carlo Simülasyonundan elde edilmiştir.

Tablo 3'e göre, REER serisi için SURADF testi ile hesaplanan test istatistiklerinin, \% 10 anlamlılık düzeyinde ele alınan tüm ülkelerde kritik değerlerden büyük olduğu tespit edilmiştir. Dolayısıyla tüm ülke setinde serinin birim kök içerdiği belirlenmiştir.

Tablo 4. NFA Değişkeni İçin Durağanlık Testi Sonuçları

\begin{tabular}{llrrr}
\hline & & \multicolumn{3}{c}{ Kritik Dĕgerler } \\
\cline { 3 - 5 } Ülke & SURADF test & $1 \%$ & $5 \%$ & $10 \%$ \\
\hline Türkiye & 2.073 & -14.668 & -10.136 & -8.400 \\
Belarus & -1.623 & 0.761 & 2.600 & 3.494 \\
Hindistan & -0.722 & -14.185 & -10.273 & -8.490 \\
Meksika & -1.396 & -14.494 & -10.587 & -8.845 \\
Polonya & -4.681 & -17.169 & -12.130 & -10.269 \\
Güney Afrika & $-3.260 * * *$ & -2.683 & -1.537 & -1.286 \\
Misır & 4.132 & -13.661 & -9.622 & -7.953 \\
Romanya & -4.056 & -13.619 & -9.677 & -8.056 \\
Gana & -7.176 & -147.336 & -110.163 & -95.589 \\
Kolombiya & $-4.133 * * *$ & -3.887 & -0.675 & 0.852 \\
Hirvatistan & -7.263 & -26.517 & -19.227 & -16.417 \\
Uruguay & $-3.401 * * *$ & -1.027 & 1.153 & 2.116 \\
Bulgaristan & -5.945 & -21.959 & -15.333 & -13.272 \\
Tunus & -5.722 & 14.976 & 20.025 & 22.910 \\
Litvanya & -5.711 & -34.252 & -15.269 & -12.422 \\
\hline Not: & & &
\end{tabular}

Not: $* * *, * * *{ }^{*}$ sırasılyla istatistiki olarak $\% 1, \% 5 \mathrm{ve} \% 10$ anlamlılık düzeyinde durağanlığı göstermektedir. Kritik değerler, 10.000 döngüyle Monte Carlo Simülasyonundan elde edilmiştir.

Tablo 4'te gösterilen sonuçlara göre, Güney Afrika, Kolombiya ve Uruguay'da SURADF test istatistik değerleri \% 1 anlamlılık düzeylerinde tablo kritik değerlerden küçük olduğundan bu ülkelerde düzey değerlerinde NFA serisinin durağan olduğu belirlenmiştir. Ancak diğer ülkelerde hesaplanan test istatistikleri kritik değerlerden büyük olduğundan düzey değerlerine göre birim köke sahip oldukları tespit edilmiştir. 
Tablo 5. PROD Değişkeni İçin Durağanlık Testi Sonuçları

\begin{tabular}{lcrrr}
\hline & & \multicolumn{3}{c}{ Kritik Değerler } \\
\cline { 3 - 5 } Ülke & SUR $\boldsymbol{D F}_{\text {test }}$ & $\mathbf{1 \%}$ & $\mathbf{5 \%}$ & $\mathbf{1 0 \%}$ \\
\hline Türkiye & -3.110 & -19.278 & -14.127 & -12.099 \\
Belarus & -1.374 & -160.061 & -128.350 & -115.121 \\
Hindistan & -0.566 & -10.302 & -7.924 & -6.538 \\
Meksika & -7.655 & -14.922 & -11.055 & -9.321 \\
Polonya & -1.096 & -23.666 & -17.634 & -14.926 \\
Güney Afrika & -1.200 & -17.520 & -13.565 & -11.791 \\
Misir & -1.597 & -7.220 & -3.779 & -2.063 \\
Romanya & -7.157 & -101.214 & -86.752 & -79.635 \\
Gana & 1.637 & -18.614 & -13.643 & -11.619 \\
Kolombiya & $-12.917 *$ & -18.823 & -13.601 & -11.643 \\
Hirvatistan & -8.590 & -24.454 & -18.234 & -15.293 \\
Uruguay & 0.830 & -26.390 & -20.262 & -17.440 \\
Bulgaristan & -4.130 & -18.939 & -13.881 & -11.680 \\
Tunus & -0.432 & -110.682 & -85.453 & -72.859 \\
Litvanya & -7.606 & -6500.028 & -5299.748 & -4730.964 \\
\hline Not:
\end{tabular}

Not: $* * *, * * * *$ sirasıyla istatistiki olarak \%1, \%5 ve \%10 anlamlılık düzeyinde durağanlığ göstermektedir. Kritik değerler, 10.000 döngüyle Monte Carlo Simülasyonundan elde edilmiştir.

Tablo 5'te gösterilen sonuçlara göre, PROD değişkeni için hesaplanan test istatistiği sadece Kolombiya'da kritik değerlerden küçüktür. Dolayısıyla Kolombiya dışında hiçbir ülkede PROD serisinin düzey değerlerde durağan olmadığg ve birim köke sahip olduğu ifade edilebilir.

Tablo 6. TOT Değişkeni İçin Durağanlık Testi Sonuçları

\begin{tabular}{lcrrr}
\hline & & \multicolumn{3}{c}{ Kritik Değerler } \\
\cline { 3 - 5 } Ülke & $\boldsymbol{S U R A D F}_{\text {test }}$ & $\mathbf{1 \%}$ & $\mathbf{5 \%}$ & $\mathbf{1 0 \%}$ \\
\hline Türkiye & -3.940 & -14.598 & -11.141 & -9.333 \\
Belarus & -1.820 & -15.208 & -11.707 & -9.941 \\
Hindistan & $-10.864 * * *$ & -2.282 & -0.078 & 1.104 \\
Meksika & -6.104 & -15.225 & -11.790 & -10.040 \\
Polonya & -7.099 & -16.735 & -11.792 & -9.378 \\
Güney Afrika & -4.575 & -12.950 & -9.294 & -7.467 \\
Misir & -0.135 & -17.451 & -13.203 & -11.232 \\
Romanya & -6.638 & -23.940 & -17.526 & -14.847 \\
Gana & 1.969 & -21.311 & -15.102 & -12.595 \\
Kolombiya & -1.813 & -22.313 & -15.878 & -13.252 \\
Hirvatistan & -15.933 & -44.985 & -34.350 & -29.506 \\
Uruguay & -2.823 & -17.255 & -13.226 & -11.356 \\
Bulgaristan & -0.526 & -18.582 & -13.147 & -11.240 \\
Tunus & -9.128 & -25.208 & -17.266 & -14.467 \\
Litvanya & -3.449 & -23.078 & -16.777 & -13.702 \\
\hline Not: & & &
\end{tabular}

Not: $* * *, * * * *$ sırasıyla istatistiki olarak $\% 1, \% 5$ ve \%10 anlamlılık düzeyinde durağanlığ 1 göstermektedir. Kritik değerler, 10.000 döngüyle Monte Carlo Simülasyonundan elde edilmiştir.

Tablo 6'da yer alan sonuçlara göre, TOT serisinin düzey değerlerinde sadece Hindistan'da durağan bir olduğu ancak diğer ülkelerde birim kök içerdiği görülmüştür.

Durağanlık testi sonuçlarına toplu olarak bakıldığında, REER serisinin tüm ülkelerde düzey değerlerinde birim köke sahip olduğu, NFA, PROD ve TOT serilerinin ise düzey 
değerlerine göre bazı ülkeler dışında pek çok ülkede birim kök sahip olduğu bulgusuna ulaşılmıştır.

Eşbütünleşme testi ve uzun dönem katsayı tahmincisi seçiminde eğim katsayılarının homojen ya da heterojen bir yapıya sahip olması belirleyici olduğundan, Delta Testi ile gerçekleştirilen homojenlik testi sonuçları aşağıdaki Tablo 7’te sunulmuştur.

Tablo 7. Homojenlik Testi Sonuçları

\begin{tabular}{lcc}
\hline & Test istatistiği & Olasılık Değeri \\
\hline Delta_tilde $(\widehat{\Delta})$ & $25.615^{* * *}$ & 0.000 \\
Delta_tilde_adj $\left(\widehat{\Delta}_{\text {adj }}\right)$ & $28.954 * * *$ & 0.000 \\
\hline
\end{tabular}

Not: $* * *, * *$ ve *, sırasıyla istatistiki olarak $\% 1, \% 5$ ve \%10 anlamlılık düzeyinde eğim katsayılarının heterojen olduğunu göstermektedir.

Tablo 7'deki sonuçlar, her iki test istatistiğinin olasılık değerleri \% 5'ten küçük olduğundan birimler arasındaki eğim katsayılarının heterojen olduğunu göstermektedir.

Durağanlık testi sonuçlarına göre bazı değişkenler bazı ülkelerde düzey değerlerinde durağan iken bazı ülkelerde durağan olmadığından ve ayrıca yatay kesit birimleri arasında eğim katsayıları heterojen olduğundan uygulanacak eşbütünleşme testinin Durbin-Hausman olmasına karar verilmiştir. Test sonuçları ise aşağıdaki Tablo 8'de verilmiştir.

Tablo 8. Eşbütünleşme Testi Sonuçları

\begin{tabular}{lcc}
\hline & Test İstatistiği & Olasılık Değeri \\
\hline Durbin-H Grup & $202.645 * * *$ & 0.000 \\
Durbin-H Panel & $64.909 * * *$ & 0.000 \\
\hline Not: $* * * * *$ ve $*$ sırasıly serilerde istatistiki olarak $\% 1, \% 5$ ve $\% 10$ anlamlılık düzeyini göstermektedir.
\end{tabular}

Tablo 8'e göre, \% 1 anlamlılık düzeyinde $H_{0}$ hipotezi reddedilmiş ve hem paneli oluşturan yatay kesit birimlerinden bazılarında hem de tüm panel için seriler arasında uzun dönemli ilişki olduğu belirlenmiştir. Bu sonuçlara göre, hem tüm panel için hem de her bir yatay kesit birimi için uzun dönem katsayı tahminlerinin yapılmasına karar verilmiştir. DSUR yöntemiyle her bir ülke için gerçekleştirilen uzun dönem katsayı tahmin sonuçları Tablo 9'da sunulmuştur. 
Tablo 9. Katsayı Tahmin Sonuçları

\begin{tabular}{|c|c|c|c|c|c|c|}
\hline \multicolumn{7}{|c|}{ Bağımlı Değişken: REER } \\
\hline & \multicolumn{2}{|c|}{ NFA } & \multicolumn{2}{|c|}{ PROD } & \multicolumn{2}{|c|}{ TOT } \\
\hline Ülkeler & Katsayı & t istatistiğ $\mathbf{i}$ & Katsayı & t istatistiğ $\mathbf{i}$ & Katsayı & $\mathbf{t}$ istatistiği \\
\hline Türkiye & $2.213 * * *$ & 158.07 & $3.141^{* * *}$ & 241.61 & 0.023 & 0.000 \\
\hline Belarus & $0.440 * * *$ & 14.19 & $2.813 * * *$ & 33.49 & $0.075 * * *$ & 75.00 \\
\hline Hindistan & $0.793 * * *$ & 99.12 & $5.364 * * *$ & 357.60 & 0.005 & 0.000 \\
\hline Meksika & $2.143 * * *$ & 194.82 & $-2.211 * * *$ & -42.52 & $0.046 * * *$ & 23.00 \\
\hline Polonya & $1.987 * * *$ & 47.31 & $5.291 * * *$ & 46.41 & $0.088 * * *$ & 88.00 \\
\hline Güney Afrika & $10.731 * * *$ & 35.42 & $22.125 * * *$ & 44.607 & $0.248 * * *$ & 88.00 \\
\hline Misir & $-2.361 * * *$ & -32.34 & $-7.112 * * *$ & -13.52 & $0.056 * * *$ & 14.00 \\
\hline Romanya & $-1.036 * * *$ & -207.00 & $-0.740 * * *$ & -74.00 & -0.007 & 0.000 \\
\hline Gana & $0.738 * * *$ & 147.60 & $2.441 * * *$ & 27.43 & $-0.038 * * *$ & -38.00 \\
\hline Kolombiya & $0.144 * * *$ & 36.00 & $0.470 * * *$ & 12.05 & -0.005 & 0.000 \\
\hline Hurvatistan & $0.443 * * *$ & 49.22 & $1.958 * * *$ & 40.79 & $-0.074 * * *$ & -74.00 \\
\hline Uruguay & $0.952 * * *$ & 25.73 & $4.268 * * *$ & 129.33 & $-0.127 * * *$ & 127.00 \\
\hline Bulgaristan & $-1.833 * * *$ & -39.85 & $0.753 * * *$ & 2.75 & $-0.024 * * *$ & -4.80 \\
\hline Tunus & $-0.027 * * *$ & -6.75 & $-8.094 * * *$ & -137.19 & 0.003 & 0.000 \\
\hline Litvanya & $-0.973 * * *$ & -97.30 & $0.421 * * *$ & 24.76 & $0.029 * * *$ & 9.67 \\
\hline
\end{tabular}

Not: $* * *, * *$ ve $*$, sırasıyla $\% 1, \% 5$ ve $\% 10$ anlamlılık düzeyini göstermektedir.

Tablo 9'da gösterilen ve SURADF yöntemiyle gerçekleştirilen katsayı tahmin sonuçlarına göre, REER üzerinde hemen tüm ülkelerde en etkili değişkenin Balassa-Samuelson etkisini temsil eden göreli verimlilik değişkeni (PROD) olduğu belirlenmiştir. PROD değişkeninin REER üstündeki etkisi Meksika, Mısır, Romanya ve Tunus dışında beklendiği yönde ve istatistiki olarak anlamlıdır. Göreli verimlilikteki artışın ülkelerin genelinde ekonomide kişi başına geliri yükselterek tüketici fiyat endeksinde artışa yol açtığı ve böylece REER'de bir artış meydana getirdiği görülmektedir. Negatif etkilerin yaşandığı ülkelerde, verimlilik artışının üretim artırıcı etkisinin maliyetleri azaltıcı etkilere sahip olduğu ve tüketim artıcı etkiden büyük olduğundan tüketici fiyat endeksine negatif olarak yansıyarak REER üzerinde negatif etkilerde bulunduğu ifade edilebilir.

Net dış pozisyonu temsilen kullanılan NFA'nın REER üzerinde tüm ülkelerde istatistiki olarak anlamlı etkilere sahip olduğu görülmektedir. Misır, Romanya, Bulgaristan ve Tunus dışında Türkiye dahil diğer ülkelerde beklenen yönde etkinin ortaya çıktığı yani NFA'daki artışın REER'yi pozitif etkilediği belirlenmiştir. Negatif etkinin ortaya çıktığı ülkelerde, yüksek faiz getirisine bağlı olarak kısa vadeli sermayeyi ülkelerine çekerek cari açığı kapatma isteği toplam yükümlülükleri artırarak NFA'nın azaltabilmektedir. Buna bağlı olarak yurtiçinde dövizin bollaşması ve ulusal paraya olan talebin artışıyla REER'nin yükselmesi mümkün olabilmektedir.

Dış ticaret haddini temsilen kullanılan TOT değişkeninin ise Türkiye, Hindistan, Romanya, Kolombiya ve Tunus dışındaki diğer 10 ülkede REER üzerinde istatistiki olarak anlamlı etkilere sahip olduğu tespit edilmiştir. Belarus, Meksika, Polonya, Güney Afrika, Mısır ve Litvanya'da gelir artırıcı etkinin ağırlıkta olduğu belirlenmiş iken Gana, Hırvatistan, Uruguay ve Bulgaristan'da ikame etkisinin ağırlıkta olduğu gözlenmiştir. 


\subsection{Sabit Etkiler Modeli İle Katsayı Tahmin Sonuçları}

Katsayı tahminlerine geçmeden önce, ilk olarak klasik modelin geçerli olup olmadığı yani birim ve zaman etkilerinin varlığı araştırılmıştır. $\mathrm{Bu}$ kapsamda klasik modeli sabit etkiler modeline karşı test eden $\mathrm{F}$ testi ile klasik modeli tesadüfi etkiler modeline karşı test eden Olabilirlik Oranı (LR) testi uygulanmıştır. F testi ve LR testi sonuçlar aşağıdaki Tablo 10'da gösterilmiştir.

Tablo 10. Birim ve Zaman Etkisi Test Sonuçları

\begin{tabular}{lllll}
\hline & \multicolumn{2}{c}{ F testi } & \multicolumn{2}{c}{ LR testi } \\
\hline & $(\boldsymbol{F}$ istatistiği $)$ & $\begin{array}{l}\text { Olasılık } \\
\text { Değeri }\end{array}$ & $\left(\chi^{2}\right.$ istatistiği $)$ & $\begin{array}{l}\text { Olasılık } \\
\text { Değeri }\end{array}$ \\
\hline Birim Etki & $32.48^{* * *}$ & 0.000 & $209.11^{* * *}$ & 0.000 \\
Zaman Etkisi & 0.52 & 0.960 & 0.00 & 1.000 \\
\hline Not: $* * *, * *$ ve ${ }^{*}$, slrasiyla $\% 1, \% 5$ ve $\% 10$ istatistiki olarak anlamllık düzeyini ifade etmektedir.
\end{tabular}

Tablo 10'daki sonuçlara göre, klasik modelin geçerli olmadığı ve hem sabit etkiler modeli hem de tesadüfi etkiler modeli kapsamında birim etkilerin olduğu ancak zaman etkilerin olmadığ 1 belirlenmiştir. Tek yönlü modelin geçerli olduğunun tespit edilmesinin ardından, katsayı tahmini için sabit etkiler modeli ya da tesadüfi etkiler modellerinden hangisinin kullanılacağına karar verebilmek için Hausman (1978) spesifikasyon testi uygulanmıştır. Hausman testi sonuçlarına göre, test istatistiğinin 26.96 değerine ve istatistiksel olarak \% 1 seviyesinde $(\mathrm{p}=0.0001)$ anlamlılığa sahip olduğu tespit edilmiştir. Kısacası test istatistiği anlamlılık derecesi 0.05 'ten küçük olduğundan $\mathrm{H}_{0}$ hipotezi reddedilerek sabit etkiler modeli ile tahmin yapılmasına karar verilmiştir.

Ayrıca modellerin etkin bir şekilde tahmin edilebilmesini engelleyen değişen varyans, otokorelasyon ve yatay kesit bağımlılı̆̆ı sorunlarının varlığı araştırılmıştır. Değişen varyansın tespiti için yapılan değiştirilmiş Wald testi sonuçlarına göre istatistik değeri (Chi2) $\chi^{2}=1016.29$ ve Prob=0.0000 şeklinde bulunmuş olup modelde değişen varyans sorunu olduğu tespit edilmiştir. Ayrıca Durbin-Watson (DW) ve Yerel En iyi Değişmez (LBI) testleri kullanılarak otokorelasyonun varlığı sınanmıştır. Test sonuçlarına göre, DW test istatistiği 0.047 ve LBI test istatistiği 0.319 olarak tespit edilmiş olup, değerler 2'den düşük olduğu için otokorelasyon sorunu olduğu görülmüştür.

Model, otokorelasyon, değişen varyans ve yatay kesit bağımlılığının olduğu varsayımı altında katsayı değerlerini etkilemeyen ve dirençli standart hatalarla tahmine izin veren Driscoll-Kraay tahmincisi ile analize tabi tutulmuştur. Katsayı tahmin sonuçları aşağıdaki Tablo 11'de yer almaktadır. 
Tablo 11. Katsayı Tahmin Sonuçları

\begin{tabular}{|c|c|c|c|c|}
\hline \multicolumn{5}{|c|}{ Bağımlı Değişken: REER } \\
\hline Bağımsız Değişkenler & Katsayı & Standart Hata & $t$ istatistiğ $i$ & Olasılık değeri \\
\hline NFA & 0.040 & 0.071 & 0.57 & 0.576 \\
\hline PROD & $1.354 * * *$ & 0.158 & 8.58 & 0.000 \\
\hline TOT & $-0.290 * * *$ & 0.053 & -5.45 & 0.000 \\
\hline Sabit (c) & $21.624 *$ & 12.253 & 1.76 & 0.099 \\
\hline$F$ istatistiği & $208.68 * * *$ & & & \\
\hline Olasılık Değeri & 0.000 & & & \\
\hline Grup içi $\mathbf{R}^{2}$ & 0.35 & & & \\
\hline
\end{tabular}

Tablo 11'de gösterilen ve panelin tümü için Sabit Etkiler Modeli ile yapılan katsayı tahmin sonuçlarına göre, net yabancı varlık stoku için kullanılan NFA değişkeninin ele alınan ülke setinde REER üstünde herhangi bir anlamlı etkiye sahip olmadığı belirlenmiştir. Göreli verimlilik için kullanılan PROD değişkeninin ise beklendiği gibi REER üstünde pozitif ve güçlü bir etkiye sahip olduğu tespit edilmiştir. Buna göre göreli verimlilikteki \% 1'lik artış REER'yi \% 1.354 oranında artırmaktadır. Dış ticaret haddini temsilen kullanılan TOT değişkeninin ise REER üzerinde istatistiki olarak anlamlı ve negatif etkilere sahip olduğu gözlenmiştir. TOT'daki \% 1'lik artışın REER'yi \% 0.290 azalttığı bulgusuna ulaşılmıştır. Bu sonuca göre ele alınan ülke setinde incelenen dönemde ikame etkisinin ağırlıkta olduğu söylenebilmektedir.

Sabit etkiler modeli ile yapılan katsayı tahmin sonuçlarına göre her bir ülke için hesaplanan uzun dönem denge döviz kuru (BEER) değerlerinin mevcut REER değerleri ile karşılaştırılması sonucu ortaya çıkan toplam sapmalar çalışmanın sonundaki EK1 ve EK2'deki tablolarda gösterilmiştir. Tahmin sonuçları, toplam sapma olarak ifade edilen REER'nin uzun dönem denge REER'den sapması açısından değerlendirildiğinde, 2008 küresel krizinin hemen tüm ülkelerin REER seviyesini etkilediği tespit edilmiştir. Hindistan, Polonya, Hırvatistan ve Litvanya'da denge kurdan sapmaların diğer ülkelere oranla daha düşük düzeyde olduğu görülmüştür. Belarus, Güney Afrika, Gana, Hırvatistan ve Tunus’ta 1995-2000 döneminde REER'nin yüksek düzeyde pozitif yönlü toplam sapmaya sahip olduğu ancak daha sonraki dönemlerde daha dengeye yönelik hareketlerin yaşandığı belirlenmiştir. 2008 küresel krizinden sonraki süreçte hem ulusal hem de küresel çapta yaşanan gelişmelere bağlı olarak Türkiye, Belarus, Polonya, Güney Afrika, Gana, Hırvatistan ve Litvanya'da REER'nin negatif yönde ayrıştığı ve negatif toplam sapmaya sahip olduğu tespit edilmiştir. Özellikle son yıllarda ABD’nin uyguladığı faiz artırıcı sıkı para politikalarının sermayenin gelişmekte olan ülkelerden gelişmiş ülkelere doğru tekrar geri dönüşünü hızlandırması, pek 
çok ülkede ulusal paraların değer kaybetmesine ve böylece REER düzeyinin aşağı yönlü seyir izlemesine yol açmaktadır. Ancak Hindistan, Mısır, Kolombiya, Uruguay ve Bulgaristan’da küresel krizden sonra toplam sapmanın pozitif yönde olduğu ve ulusal paraların değer kazandığı bulgusuna ulaşılmıştır. Bunda gelişmiş ülkelere oranla daha yüksek faiz oranlarına sahip olmaları ve kısa vadeli sermaye akımlarını ülkelerine çekmeleri etkili olmaktadır.

İncelenen dönem itibariyle Türkiye ele alındığında, REER'nin, 1998-2000 yılları arasında uygulanan sabit döviz kuru politikalarına bağlı olarak pozitif yönde sapma gösterdiği; 2001 yılında yaşanan krizle birlikte denge düzeyinin altına kadar gerilediği ve 2002 yılından sonra ise ilk yıllarda siyasi istikrar ve küresel ekonomik konjonktürden dolayı yabancı sermaye girişindeki artışa bağlı olarak denge seviyesine göre yüksek düzeyde olduğu söylenebilir. Yukarıda da ifade edildiği gibi 2001 yılından itibaren REER denge seviyesine göre yukarı yönlü olup, pozitif yönde toplam sapmalar yaşanmıştır. Ampirik bulgulara göre özellikle 2003 yılından itibaren REER uzun dönem denge seviyesine göre istikrarlı olarak yüksek seviyeli konumunu korumuştur. Ancak küresel krizinin etkisinin hissedildiği 2009 yılı ile ulusal paranın ya da reel efektif döviz kurunun aşırı değerli olmasına bağlı olarak tüketim amaçlı ithalatın ve cari açığın sürdürülemez görülerek döviz kuruna müdahale edildiği 2011 yıllarında REER seviyesinde dengeye doğru keskin düşüşler meydana gelmiştir. Sonraki süreçte ülke içinde yaşanan bazı olaylar ve ekonomik kırılganlıktaki artış TL'ye olan güvenin azalarak ulusal paranın değer kaybetmesine ve dolayısıyla REER'nin denge düzeyine göre negatif toplam sapmaya sahip olmasına yol açmıştır.

\section{SONUÇ}

2000'li yılların başından itibaren gelişmekte olan ülkelerin çoğunda sermaye girişlerindeki artıştan dolayı ulusal para değerlenme eğilimine girmiş ve reel efektif döviz kuru artış göstermiştir. Aynı dönemde pek çok gelişmekte olan ülkede sürekli ve büyük boyutta cari açık sorunu yaşanmıştır. Konjonktürel hareketlerin değerlendirilebilmesi ve cari açığa etkisinin görülebilmesi amacıyla, reel efektif döviz kurlarının denge düzeylerinin araştırılıp dengeden sapma boyutlarının belirlenmesi hususu ekonomistlerin çokça üzerinde durduğu konulardan biri olmuştur. Bu çalışmada 1995-2016 döneminde Türkiye'nin de içinde bulunduğu cari açık sorunu yaşayan seçilmiş 15 gelişmekte olan ülke için BEER yaklaşımıyla uzun dönem denge döviz kurunun araştırılması sonucunda, hem makroekonomik temellerin döviz kuru üzerindeki etkisi belirlenmiş hem de uzun dönem denge döviz kuru hesaplanarak dengeden sapmalar tespit edilmiştir.

İncelenen dönemde her bir yatay kesit birimi için yani her bir ülke için yapılan katsayı tahmin sonuçlarına göre, döviz kuru üzerinde en etkili değişskenin Balassa-Samuelson etkisini 
temsil eden kullanılan göreli verimlilik olduğu tespit edilmiştir. Sonrasında net dış pozisyonu temsil eden net yabancı varlık stokunun da önemli derece etkili olduğu sonucuna varılmıştır. Hesaplanan uzun dönem BEER ve buna bağlı olarak elde edilen toplam sapma değerlerine göre, küresel krizin reel efektif döviz kurları üzerinde önemli etkilerinin olduğu görülmüştür. Hindistan, Polonya, Hırvatistan ve Litvanya'da REER'nin diğer ülkelere oranla uzun dönem denge seviyelerine yakın seyrettiği ancak Güney Afrika, Mısır, Gana, Kolombiya, Uruguay, Bulgaristan ve Tunus'ta denge düzeyinden sapmanın daha yüksek olduğu belirlenmiştir. Meksika'da 1995-1999 ve 2015-2016 dönemi dışında toplam sapma pozitif yönde ayrışmış yani REER denge düzeyine göre aşırı değerli olmuştur. Belarus'ta REER 1999 yılına kadar denge seviyesine göre aşırı değerli iken, 2000'li yıllardan itibaren denge düzeyinin altında bir görünüm almaya başlamış ve özellikle küresel krizden sonra 2016 yılına kadar denge düzeyinden sapma negatif yönde gittikçe büyümüştür. Romanya'da REER serisi 2004 yılına kadar denge düzeyine göre negatif toplam sapmaya sahip iken sonraki dönemlerde sermaye girişlerindeki artışın etkisiyle aşırı değerli bir görünüm kazanmıştır. Küresel krizden sonra ise dengeye yakın seyretmiştir.

Türkiye ele alındığında, uzun dönem reel efektif döviz kuru üzerindeki en önemli değişkenin Alper (2010) tarafından yapılan çalışmaya benzer şekilde göreli verimlilik değişkeni olduğu görülmüştür. Net yabancı varlık stokundaki değişmenin uzun dönem REER üzerinde önemli etkiler yarattığı ancak dış ticaret haddindeki değişikliğin herhangi anlamlı bir etkiye yol açmadığı belirlenmiştir. Hesaplanan uzun dönem BEER değerlerine bağlı olarak, REER'nin Türkiye'deki seyri ise genel olarak krizlerin habercisi niteliğindedir. 2001 krizinden önce yüksek cari açık sorununun olduğu dönemde pozitif toplam sapmaya sahip olup aşırı değerli bir görünüm sergileyen REER, 2002 yılından sonra siyasi istikrarın sağlanması ve küresel ekonomik koşullara bağlı olarak yabancı sermayedeki girişin artmasıyla birlikte denge seviyesine göre yine pozitif ayrışmış ve aşırı değerli konuma gelmiştir. REER, küresel krizin etkisini gösterdiği 2009 y1lında ve ekonomideki kırılganlıkların artışına bağlı olarak cari açığın düşürülmesi amacıyla uygulanan politikaların etkisini gösterdiği 2011 yılında sert düşüş yaşamıştır. Sonraki yıllarda ise ülke içinde yaşanan bazı olaylar ve ABD'nin sıkılaştırıcı politikalar uygulama eğilimine girmesi sonucunda REER artan negatif toplam sapma ile denge düzeyine göre düşük değerli olarak kalmaya devam etmiştir. Bu durum ulusal paranın diğer paralar karşısında değersiz olduğunu göstermekte ve günümüzde ihracata dayalı büyüme politikalarının uygulandığı bir süreçte önemli firsatlar yaratmaktadır. Ancak üretim ve ihracat yapısı ithalata dayalı olduğundan, ulusal paranın değer kaybetmesi ithal edilen ara malların pahalı hale gelmesine neden olarak üretim ve ihracat 
miktarını olumsuz etkilemektedir. Bu koşullar altında dışa bağlı üretim yapısından kurtulmak büyük önem arz etmektedir.

Chang ve Grabel (2004) tarafından belirtildiği gibi seçici sanayi politikalanı uygulanarak belirlenen sanayi kollarına düşük faizli kredilerin sağlanması, ihracat sübvansiyonları, şirketler için verilecek diğer sübvansiyonlar ve ar-ge faaliyetleri ile mesleki eğitime çeşitli desteklerin verilmesi uluslararası alanda daha rekabetçi bir üretim yapısının ortaya çıkmasını sağlayacaktır. Ancak şunu da belirtmek gerekir ki, verilen destekler için devletin yapacağı sık1 gözetimler ve performans değerlendirme sistemi kaynakların verimli şekilde kullanılması açısından olmazsa olmazdır. Ayrıca Çin ve Hindistan'da uygulandığı gibi özel sektör şirketleri dış borç yükümlülüğü altına gireceğinde, kredinin vade yapısına ve kullanım amacına göre devletten onay alması gereklidir. Bu uygulama ile kaynaklar verimli alanlara tahsis edilerek ülkenin üretim yapısı dışa bağlı olmaktan kurtulabilir ve dış finansal kırılganlık azalabilir. Dışa bağlı üretim yapısından kurtulmayı sağlayacak bu ve farklı diğer politikaların uygulanması ile REER'de dengeye göre negatif sapmanın dış ticaret ve üretim üzerinde olumlu etkilerinden söz edilebilir. Yoksa uygulanacak döviz kuru politikalarının herhangi bir olumlu etkisi söz konusu olmayacaktır.

Sonuç olarak BEER yaklaşımıyla elde edilen uzun dönem denge döviz kurlarının, krizlerin öncüsü olması ya da krizlerden önemli düzeylerde etkilenmesi bakımından ekonomideki istikrar ya da istikrarsızlıkların önemli bir göstergesi olduğu tespit edilmiştir. $\mathrm{Bu}$ bilgiler 1şı̆̆ında, BEER yaklaşımının uygulanmakta olan döviz kuru politikaları için iyi bir değerlendirme olanağı sağladığı ve gelecek dönemlerde uygulanabilecek politikalar için de faydalı bilgiler sunabileceği ifade edilebilir.

\section{KAYNAKÇA}

Achy, L. (2001). Equilibrium Exchange Rate and Misalignment: In Selected MENA Countries, Munich Personal RePEc Archive, Working Paper No. 4799, 1-23.

Adu, R., Litsios I., \& Baimbridge, M. (2018). Real Exchange Rate and Asymmetric Shocks in the West African Monetary Zone (WAMZ), Journal of International Financial Markets, Institutions and Money, 1-18.

Akram, Q.F. (2003). Real equilibrium exchange rates for Norway, in O. Eitrheim \& Gulbrandsen, K.(Ed.), Explaining Movements in The Norwegian Exchange Rate (s. 53-81), Norges Bank Occasional Papers, No. 32.

Alberola, E. (2003). Misalignment Liabilities Dollarization and Exchange Rate Adjustment in Latin America, Bank of Spain Research Paper, No. 0309, 1-26.

Alper, M.A. (2010). Sürdürülebilir reel döviz kuru: Türkiye örneği (Doktora Tezi). Ankara Üniversitesi Sosyal Bilimler Enstitüsü, Ankara.

Amoah, L., \& Aziakpono, M.J. (2015). Exchange rate behaviour in Ghana: Is there a misalignment?, The Economic Society of South Africa Conference, 2nd - 4th September, Soth Africa: Cape Town.

Benassy-Quere, A., Bereau, S., \& Mignon, V. (2010). On the complemetarity of equilibrium exchange rate approaches. Review of International Economics, 18(4), 618-632.

Breuer, J. B., Mcnown, R. \& Wallace, M. S. (2001). Misleading inferences from panel unit-root tests with an illustration from purchasing power parity. Review of International Economics, 9, 482-493. 
Breuer, B., Mcnown, R., \& Wallace, M. (2002). Series specific unit root test with panel data. Oxford Bulletin of Economics and Statistics, 64(5), 527-546.

Chang, H.J. \& Grabel, I. (2004). Kalkınma yeniden: Alternatif iktisat politikalarl el kitabı (2. Bask1). Ankara İmge Kitabevi.

Chen, J. (2007). Behavior equilibrium exchange rate and misalignment of renminbi: A recent empirical study, Degit Conference Paper, 1-21.

Cheng, F.D., \& Orden, D. (2005). Exchange rate misalignment and its effects on agricultural producer support estimate: empirical evidence from India and China. Markets, Trade and Institution Division (MTID) Discussion Paper, International Food Policy Research Institute, No. 81, 1-27.

Clark, P.B., \& R. MacDonald. (1998). Exchange rates and economic fundamentals: A methodological comparison of BEERs and FEERs, International Monetary Fund, Working Paper, No. 67, 1-37.

Couharde, C., Coulibaly, I., \& Damatte, O. (2013). Anchor Currency and Real Exchange Rate Dynamics in the CFA Franc Zone, Economic Modelling, 33, 722-732.

Çemrek, F., \& Burhan, E. (2014). Petrol tüketiminin ekonomik büyüme üzerindeki etkisinin panel veri analizi ile incelenmesi. Uluslararası Alanya İşletme Fakültesi Dergisi, 6(3), 47-58.

Çetin, M., \& Ecevit, E. (2010). Sağlık harcamalarının ekonomik büyüme üzerindeki etkisi: OECD ülkeleri üzerine bir panel regresyon analizi. Doğuş Üniversitesi Dergisi, 11(2), 166-182.

Darvas, Z. (2012). Real Effective Exchange Rates for 178 Countries: A New Database, Bruegel, Working Paper No. 6, 1-34.

Dufrenot, G.J. \& Yehoue, E.B. (2005). Real exchange rate misalignment: a panel co-integration and common factor analysis. International Monetary Fund, Working Paper No.164, 1-38.

Egert, B., Halpern, L., \& Macdonald, R. (2005). Equilibrium exchange rates in transition economies: Taking stock of the issues, William Davidson Institute, Working Paper No. 792, 257-324.

Elbadawi, I., A., Kaltani, L., \& Soto, R. (2012). Aid, real exchange rate misalignment, and economic growth in Sub-saharan Africa. World Development, 40(4), 681-700.

Feyzioğlu, T. (1997). Estimating the Equilibrium Real Exchange Rate: An Application to Finland, International Monetary Fund, Working Paper No. 109, 1-24.

Fidora, M., Giordano, C., \& Schmitz, M. (2017). Real Exchange Rate Misalignments in The Euro Area, European Central Bank, Working Paper No. 2108, 1-54.

Funke, M., \& Rahn, J. (2005). Just How Undervalued Is the Chinese Renminbi? World Economy, 28, 465-489.

Greene, W.H. (2000). Econometric analysis (Fourth Edition). New Jersey: Prentice Hall.

Gujarati, D.N., \& Porter D. C. (2009). Basic Econometrics, Fifth Edition, McGraw Hill Educations, New York.

Hill, R.C., Griffiths, W.E., \& Lim, G.C. (2011). Principles of Econometrics, Fourth Edition, John Wiley \& Sons, United States of America.

Hsiao, C. (2003). Analysis of Panel Data, Second Edition, Cambridge University Press, Cambridge: England.

IMF. (2007). The Equilibrium Exchange Rate: Alternative Concepts and Their Applications in IMF Surveillance, Background Document, 3, 53-66.

Iossifov, P., \& Loukoianova, E. (2007). Estimation of A Behavioral Equilibrium Exchange Rate Model for Ghana, International Monetary Fund, Working Paper No. 155, 1-21.

Jongwanich, J. (2008). Real exchange rate overvaluation and currency crisis: Evidence from Thailand. Applied Economics, 40(3), 373-382.

Khomo, M. M. \& Aziakpono, M. J. (2016). The behaviour of the real effective exchange rate of South Africa: Is there a misalignment? Economic Research Southern Africa, 644, 1-23.

Kinkyo, T. (2008). Disorderly adjustments to the misalignments in the Korean Won. Cambridge Journal of Economics, 32, 111-124.

Komaludin, A. (2009). Determinant factors of real exchange rates: the behavioral equilibrium exchange rates model (The BEER). Jurnal Ekonomi Dan Bisnis, 15(1), 1-15.

Komárek, L., \&. Melecký, M. (2005). the behavioural equilibrium exchange rate of the czech koruna, Czech National Bank, Working Paper No. 5, 1-24.

Lane P. R., \& Milesi-Ferretti, G. M. (2001). The external wealth of nations: measures of foreign assets and liabilities for industrial and developing countries. Journal of International Economics, 55, 263-294.

Leung, F., \& Ng, P. (2007). Is the Hong Kong dollar real exchange rate misaligned? Hong Kong Monetary Authority, Working Paper No. 21.

MacDonald, R. (1997). What determines the real exchange rate? The long and the short of it, IMF, Working Paper No. 97(21), 1-53.

MacDonald, R. (2000). Concepts to calculate equilibrium exchange rates: an overview, Deutsche Bank, Economic Research Group, Discussion Paper No. 3, 1-66.

MacDonald, R. (2004). The long-run real effective exchange rate of singapore: A behavioural approach. Monetary Authority of Singapore, Staff Paper No. 36, 1-28. 
MacDonald, R., \& Dias, P. (2007). behavioural equilibrium exchange rate estimates and implied exchange rate adjustments for ten countries, University of Glasgow, Department of Economics, Working Paper No. 12, 1-33.

Maeso-Fernández, F., Osbat, C.,\& Schnatz, B. (2002). Determinants of the euro real effective exchange rate: A BEER/PEER Approach. Australian Economic Papers, 41, 437-461.

Mark, N.C., Ogaki, M. \& Sul, D. (2005). Dynamic seemingly unrelated cointegrating regressions. The Review of Economic Studies, 72(3), 797-820.

Paiva, C. (2006). External adjustment and equilibrium exchange rate in Brazil, International Monetary Fund, Working Paper No. 221, 1-21.

Pesaran, M. H. (2004). General diagnostic tests for cross section dependence in panels. Cambridge Working Papers in Economics, 435, 1-39.

Pesaran, M. H. \& Yamagata, T. (2008). Testing slope homogeneity in large panels. Journal of Econometrics, 142(1), 50-93.

Pesaran, M. H., Ullah, A. \& Yamagata, T. (2008). A bias-adjusted LM test of error cross-section independence. Econometrics Journal, 11, 105-127.

Plecita, K., \& Strelec, L. (2012). Behavioral equilibrium exchange rate in Greece and İreland, Proceedings of 30th International Conference Mathematical Methods in Economics, 715-720.

Rusek, A. (2012). The Eurozone's equilibrium real exchange rates. Modern Economy, 3(5), 534-541.

Sahminan, S. (2005). Estimating equilibrium real exchange rates of the rupiah, Bank Indonesia, Working Paper No.8, 1-13.

Schnatz, B., Vijselaar, F., \& Osbat, C. (2003). Productivity and the (synthetic) euro-dollar exchange rate, European Central Bank, Working Paper Series No.225, 1-36.

Siregar, R. Y. (2011). The concepts of equilibrium exchange rate: A survey of literature, The South East Asian Central Banks Research and Training Center, Staff Paper No. 81, 1-54.

Tatoğlu, F. Y. (2012). Panel veri ekonometrisi (1. Bask1). İstanbul: Beta Yayınevi.

Tipoy, C. K., Breitenbach, M. C., \& Zerihun, M. F. (2016). Equilibrium exchange rates and misalignments: The case of homogenous emerging countries. SPOUDAI Journal of Economics and Business, 66(4), 3-25.

Toulaboe, D. (2006). Real exchange rate misalignment and economic growth in developing countries. Southwestern Economic Review, 33, 57-72.

Verbeek M. (2004). A guide to modern econometrics (Second Edition). West Sussex: John Wiley \& Sons Ltd.

Vieira, F. V, \& MacDonald, R. (2012). A panel data investigation of real exchange rate misalignment and growth. Estudos Econômicos (São Paulo), 42(3), 433-456.

Villavicencio, A. L. (2006). Real equilibrium exchange rates: A panel data approach for advanced and emerging economies. Economie Internationale, 108, 59-81.

Wang, T. (2004). Exchange rate dynamics, in Prasad, E. (Ed.), China's Growth and Integration Into The World Economy: Prospects and Challenges, International Monetary Fund, Occasional Paper No. 232.

Westerlund, J. (2008). Panel cointegration tests of the fisher effect. Journal of Applied Econometrics, 23(2), 193 233.

Yajie, W., Xiaofeng, H., \& Soofi, A. S. (2007). Estimating Renmibni (RMB) equilibrium exchange rate. Journel of Policy Modeling, 29, 417-429.

Zhang, Z. (2001). Real exchange rate misalignment in China: An empirical investigation. Journal of Comparative Economics, 29, 80-94. 


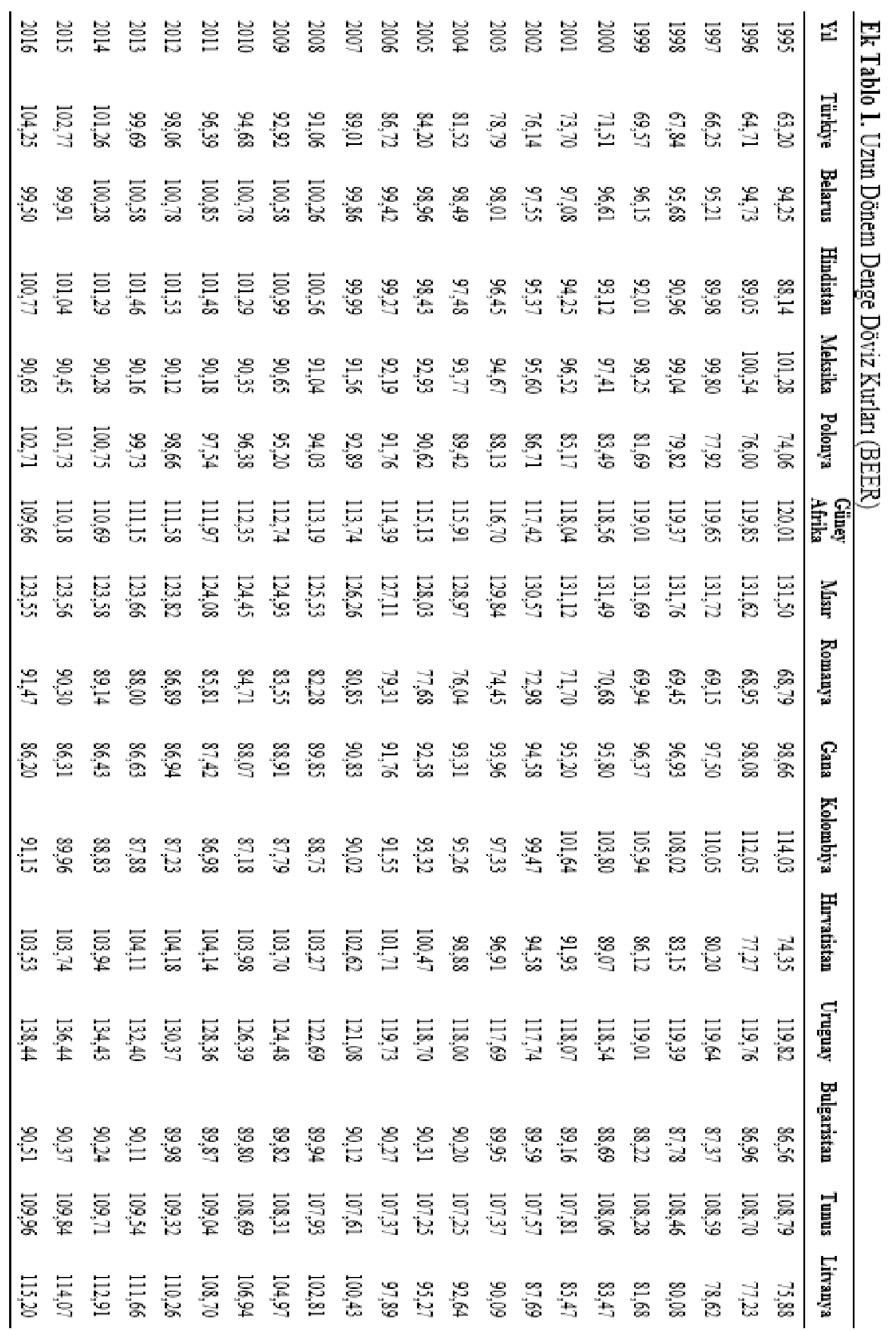




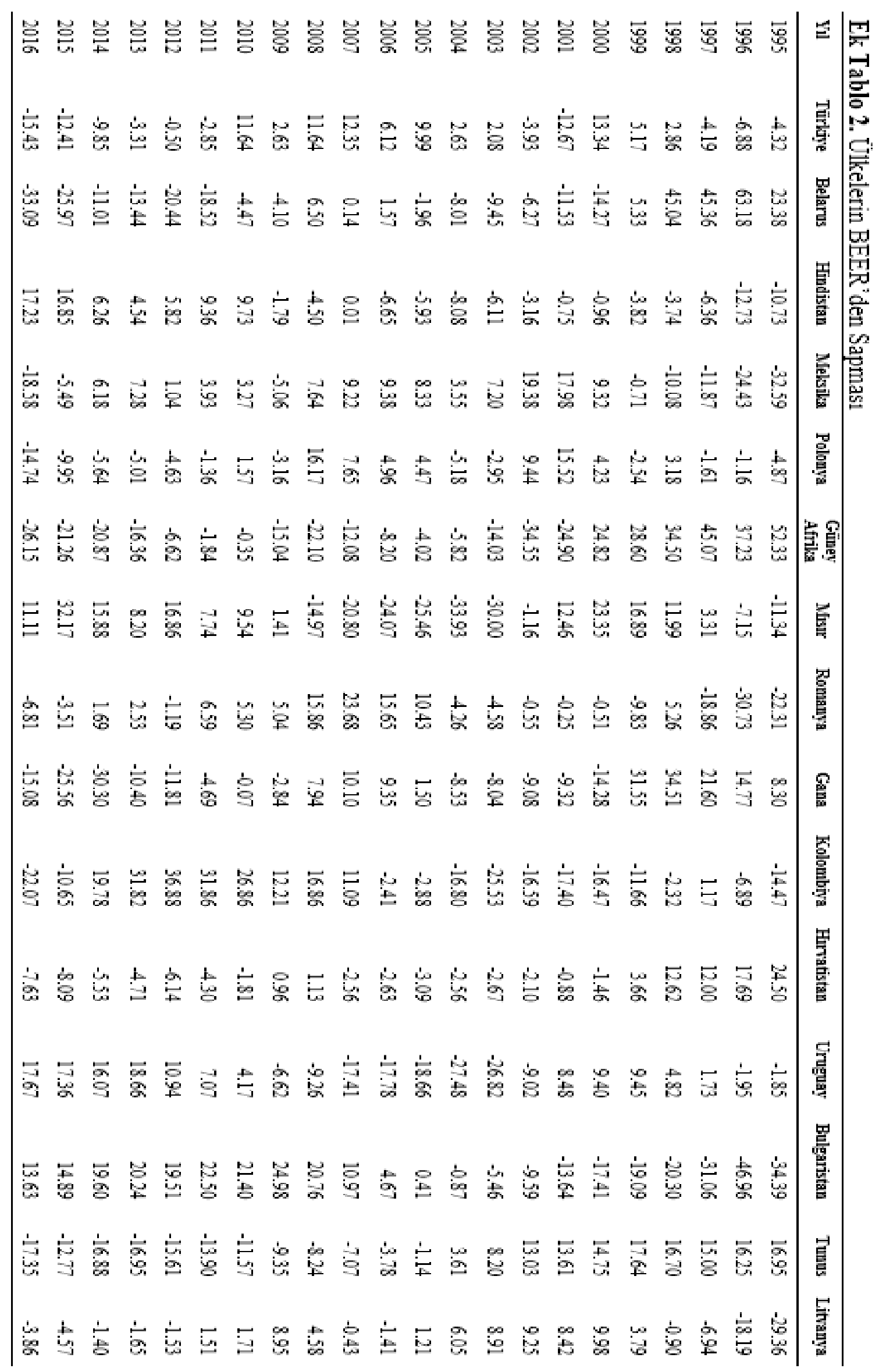




\section{EXTENDED ABSTRACT}

Since the beginning of the 2000 s, the real effective exchange rates entered into an increasing trend in many of the developing countries because of the high level of capital inflow and, thus, the local currencies experienced an appreciation period. In order to determine the effect on the economic equilibrium and consequently on the current account deficit, it became necessary to investigate the equilibrium real effective exchange rates and to determine the misalignments. Performing this analysis for the other countries having a current deficit problem is very important for both determining the equilibrium real effective exchange rates in the countries, which experience the same problem, and to compare the effects. The objective of this study is to estimate the equilibrium exchange rate for the period 1995-2016 for 15 countries affected from the capital movements and exchange rate uncertainty and experiencing current deficit problem such as Turkey, as well as determining the misalignments from the equilibrium level. The BEER (Behavioral Equilibrium Exchange Rate) method used for this purpose is based on the studies carried out by Macdonald (1997) and Clark and Macdonald (1998). This approach was derived from the simple assumptions of uncovered interest parity approach and is generally used for analyzing the periodical movements of real effective exchange rates. It analyzes the main determinants and the source of the periodic or temporal movements of the real effective exchange rate and aims to explain the behavior of exchange rates.

Within the scope of empirical analysis, the real effective exchange rate index is used as the dependent variable. On the other hand, among the independent variables, the net foreign asset stock represents the net foreign position and relative productivity representing the BalassaSamuelson effect, and the terms of trade data were used for the foreign prices. In the first phase of analysis, the cross-sectional dependence was tested and then SURADF (Seemingly Unrelated Regression Augmented Dickey-Fuller) panel unit root test is used for analyzing the stationarity of the series. In the next phase, Delta test was applied for determining of slope homogeneity and, then, the presence of a long-term relationship between the series was examined by using Durbin-Hausman cointegration test. Finally, the coefficient estimations were made by using the DSUR (Dynamics SUR) method and fixed effects model.

According to the coefficient estimations made specifically for each country, it was determined that the most important variable influencing the real effective exchange rate was the relative productivity representing the Balassa-Samuelson effect. The net foreign asset stock was found to be significantly effective. According to the long-term REER calculated in accordance with the fixed effects model and the total misalignments obtained from those calculations, it was 
determined that the global crisis has significant effects on the real effective exchange rates. REER of India, Poland, Croatia, and Lithuania coursed closer to the long-term equilibrium levels when compared to the other countries but the deviation from the equilibrium level was higher in South Africa, Egypt, Ghana, Colombia, Uruguay, Bulgaria, and Tunisia. In Mexico, except for the periods 1995-1999 and 2015-2016, the total misalignment differed in a positive direction; in other words, REER was overvalued when compared to the equilibrium level. In Belarus, the REER was overvalued until the equilibrium level in 1999, whereas it decreased below the equilibrium level since the 2000s and the misalignments grew in the negative direction until 2016. In Romania, the REER series had a negative total misalignment until 2004 however it gained an overvalued status under the effects of an increase in the capital inflows in the next periods. However, it coursed close to the equilibrium after the global crisis.

Considering Turkey, similarly to the study carried out by Alper (2010), it was determined that the most important variable for the long-term real effective exchange rate is relative productivity. Moreover, it was also determined that the change in the net foreign asset stock had significant effects on the long-term REER but the change in terms of trade did not cause any significant effect. Depending on the calculated long-term BEER values, the course of REER in Turkey is generally an indicator of crisis. In the period before 2001, when there was the problem of the high-level current account deficit, the REER had positive misalignment and was overvalued. After 2002, together with the increase in foreign capital inflow because of the political stability and global economic conditions, it positively deviated from the equilibrium level and it became overvalued. In 2009, when the effects of the global crisis were observed, and 2011, when the effects of policies implemented in order to decrease the current account deficit, the sharp falls were observed in REER. In the next years, because of specific events and the beginning of the USA's contractionary monetary policies, REER remained undervalued with increasing negative total misalignment. This suggests that the local currency was undervalued when compared to the other currencies and it offers important advantages in a period, in which the export-led growth policies were applied. However, since the problem is the import-based structure of production and export, the local currency's depreciation makes the imported intermediate products more expensive and negatively affects the amount of production and consequently exports. Under these conditions, the policies that will change the foreign-dependent production structure can be achieved by means of the incentives and guidance to be provided by the government and the positive effects of the negative total misalignment can be achieved for REER. 
In conclusion, it was determined that the long-term real effective exchange rates obtained by using the BEER approach are an important indicator of stability or instability in the economy since they are the precursor of crises or significantly affected from the crises. In the lights of this information, it can be stated that BEER approach offers the opportunity of better evaluating the exchange rate policies being implemented and it might offer useful information for the policies that will be implemented in the future. 